Western University

Scholarship@Western

Earth Sciences Publications

Earth Sciences Department

2016

A Brief Account of New Petrographic and Isotopic Insights into the Hertfordshire and Buckinghamshire Puddingstones of SE England

Jennifer Huggett

Petroclays, East Sussex, England

Fred Longstaffe

The University of Western Ontario, flongsta@uwo.ca

Follow this and additional works at: https://ir.lib.uwo.ca/earthpub

Part of the Geology Commons

Citation of this paper:

Huggett, Jennifer and Longstaffe, Fred, "A Brief Account of New Petrographic and Isotopic Insights into the Hertfordshire and Buckinghamshire Puddingstones of SE England" (2016). Earth Sciences Publications. 19.

https://ir.lib.uwo.ca/earthpub/19 


\title{
A brief account of new petrographic and isotopic insights into the Hertfordshire and Buckinghamshire Puddingstones of SE England
}

Jennifer Huggett ${ }^{1}$ and Fred J. Longstaffe ${ }^{2}$

\begin{abstract}
Determining the process of silicification in silcretes is essential to understanding their environmental significance. For the late Paleocene silcretes of the Anglo-Paris basin this is of particular interest due to their association with the PETM (Paleocene-Eocene Thermal Maximum). Here puddingstone samples from Hertfordshire and Buckinghamshire have been examined by optical, BSEM and CL petrography, X-ray diffraction and oxygen isotope analysis.

The range of quartz sand luminescence colours indicates a diverse provenance. Flint pebbles show little variability, consistent with a single source. The oxygen isotope compositional range of the flint pebbles is consistent with chemical sedimentation at normal temperatures from Cretaceous seawater, and with the pebbles being derived from the Chalk Group (Upper Cretaceous). The majority of pebbles are well rounded and have an outer zone that is either iron-stained or weathered. Fracturing of pebbles typically post-dates the weathering/oxidation and pre-dates deposition of the pebble bed. A small proportion of the pebbles have been fractured in situ; this fracturing post-dates deposition and pre-dates silicification.

Matrix fabrics are diverse, ranging from very fine sand with a cryptocrystalline quartz cement to medium sand with macro-quartz cement with luminescence zoning. Minor formation of authigenic Ti oxides has occurred and locally authigenic Fe oxides are abundant. Ti oxides formed during, or immediately before, silcrete formation, while the Fe oxides are possibly associated with more recent weathering. The oxygen isotope data for the silica cement are consistent with silcrete formation from highlands-derived, low $-{ }^{18} \mathrm{O}$ meteoric groundwater at warm near-surface temperatures.
\end{abstract}

Key Words: silcrete, puddingstone, silicification, isotope, cathodoluminescence

${ }^{1}$ Petroclays, The Oast, Sandy Cross, Heathfield, East Sussex, TN21 8QP, UK

${ }^{2}$ Department of Earth Sciences, The University of Western Ontario, London, Ontario, N6A 5B7, Canada

Corresponding Author Jennifer Huggett. email address: info@petroclays.com, tel. 01435862485 


\section{INTRODUCTION}

The Hertfordshire Puddingstone (HPS) occurs discontinuously over chalk in association with the Reading and Upnor formations of the Lambeth Group (Paleocene/Eocene) sediments. Despite the name it is not restricted to Hertfordshire, but occurs in a broad arc north of London (Figure 1). There are a few well-documented in situ occurrences of the HPS in the Upnor Formation (e.g. Moffat and Catt, 1983; Robinson, 1994; Lovell and Tubb, 2006; Tubb, 2015). Whether the HPS formed in the Reading Formation (Catt and Doyle, 2010; Tubb, 2015) or the underlying Upnor Formation (Small, 1980; Young and Lake, 1988; Lovell and Tubb, 2006; Aldiss, 2012) has been much debated, due to localised pedogenesis of the Upnor Formation, and the paucity of body faunal or trace fossils. Lovell (2015) asserts that these differences of opinion are purely nomenclatural, and following Knox (1996) the HPS belongs to depositional sequence Lambeth-2, directly above an unconformity (Figure 2). Lovell (2015) tentatively proposes that cementation of the Colliers End HPS (Figure 1) and associated mudstones occurred in a tropical or sub-tropical climate in the latest Thanetian; the subsequent Mid Lambeth Hiatus (earliest Ypresian), resulted in the intense weathering and silicification of the pebble bed (Page and Skipper, 2000; Aldiss, 2012; Entwistle et al. 2013).

The HPS is a type of silcrete. Silcrete is an indurated rock produced by the near-surface accumulation of secondary silica within a soil, sediment, rock or weathered material (Summerfield, 1983; Milnes and Thiry, 1992). The HPS is a silcrete formed in a pebble bed, and is characterised by a variety of fabric types, reflecting the diversity of the host sediment. The pebbles may be rounded or angular fragments, while the sandy matrix fabric is usually grainsupported. In the UK Tertiary silcretes without pebbles are commonly referred to as sarsens. The composition is dominated by quartz, in the form of pebbles in a sand matrix with a quartz cement. Small amounts of Ti oxides and $\mathrm{Fe}$ oxides, plus rare feldspar and kaolinite, are also typically present in the HPS, as in other types of silcrete.

A non-pedogenic groundwater origin has been proposed for most silcretes in the southern UK on the basis of (i) the absence of complex profile structures, (ii) tabular macromorphology, and (iii) the simple micromorphology of most boulders (Ullyott et al. 1998, 2004). Lovell (2015), however, argues for formation prior to deposition of overlying mudstones, but beneath a land surface exposed to intense weathering during the Paleocene-Eocene Thermal Maximum (PETM), or shortly after during the earliest Ypresian (Figure 2). The PETM commenced 55.8 Ma ago (Lourens et al. 2004) and lasted $\sim 170,000$ years (Röhl et al. 2007). This duration defines the time during which the HPS was most likely cemented. At the start of the PETM, average global temperatures increased by approximately $6{ }^{\circ} \mathrm{C}$ within about 20,000 years (Thomas and Shackleton, 1996); this thermal maximum lasted approximately $170 \mathrm{ka}$ (Röhl et al. 2007).

\section{MATERIALS AND METHODS}


HPS samples were examined from five localities to the north and northwest of London: Chesham, Bradenham Coppice and Ley Hill in Buckinghamshire, and Puckeridge and Northaw Great Wood in Hertfordshire (Figure 1). A sample of uncemented sand was obtained from the surface of one of the Colliers End HPS boulders (Figure 1). This was analysed to determine if it was purely the sand matrix, minus its cement, from the HPS boulder on which it rested, or whether it might have another origin. The in situ Northaw Great Wood sample provided the opportunity to assess both the sediment that hosted the HPS formation, and the changes wrought by pedogenesis and silcrete formation on the original sediment. To this end, two samples of the enclosing clay-rich sediment were obtained from adjacent to the Northaw Great Wood HPS.

The samples were selected to demonstrate a range of macro- and micromorphological features. Samples were initially examined in hand specimen, and then in thin-section to determine variations in micromorphology. The macromorphological features and field relations of the silcretes at each site are described in Table 1. Cathodoluminescence $(C L)$ images were obtained from polished thin sections of all samples, using a Zeiss EVO Scanning Electron Microscope (SEM) with a Gatan Chrome CL attachment, which is sensitive in the visible light range. A beam dosage of $3 \mathrm{nA}$ at $20 \mathrm{kV}$, and a short dwell time of 20 microseconds were used for the imaging. The total image dwell time is 26.2 mins $\left(512^{2}\right.$ pixels/image). These operating conditions allow images to be obtained without beam damage to the sample. Energy dispersive Spectra (EDS) were collected using an Oxford Instruments detector.

In preparation for oxygen isotopic analysis, 1-3 mg separates of quartz matrix /cement ( 7 samples) and flint pebbles and fragments (5 samples) were extracted carefully from two slabs of the Bradenham Coppice puddingstone by hand picking and micromilling. The purity of each component was evaluated using optical and scanning electron microscopy. Based on the microscopic examination, quartz cement purity was better than $95 \%$, including three samples containing $\sim 0.1 \mathrm{~mm}$ quartz grains that could not be removed. Flint sample purity was better than $98 \%$, based on the microscopic observations. A miniaturized, high-vacuum oxygen extraction line was utilized to convert 0.9 to $1.2 \mathrm{mg}$ samples into oxygen gas $\left(\mathrm{O}_{2}\right)$ for isotopic analysis. This apparatus was designed following Clayton and Mayeda (1963) and Leng and Sloane (2008), with modifications to reduce oxygen blanks and to facilitate direct collection of $\mathrm{O}_{2}$ rather than requiring its conversion to carbon dioxide. This approach ensured the analytical accuracy and reproducibility typically obtained using the more conventional approach of Clayton and Mayeda (1963), which requires larger samples ( $8 \mathrm{mg})$. Further details of the methodology can be obtained from the authors.

The oxygen-isotope measurements were performed using a Thermo Scientific MAT-253 dual inlet, stable isotope ratio mass spectrometer. All oxygen isotope results are reported using standard $\delta$-notation in per mil (\%o) relative to VSMOW. Accuracy was evaluated using an internal quartz standard: measured $\delta^{18} \mathrm{O}=+11.4 \pm 0.5 \%$ (accepted, $+11.5 \%$ ), and Snowbird Quartz, measured $\delta^{18} \mathrm{O}=+16.5 \%$ (accepted, $+16.2 \%$ ). Reproducibility for one sample for which sufficient material was available for duplicate analysis 
was better than $\pm 0.1 \%$. A description of each sample analyzed for its oxygen isotopic composition is given in Table 2.

Fluid Inclusion analysis by microthermometry was attempted on a doubly polished rock wafer ( 100 $\mu \mathrm{m}$ in thickness) of the Bradenham sample, using a Linkam controller and heating-cooling stage mounted on a Nikon petrographic microscope. The analytical and interpretational methods have been practised for over 150 years and are described in many publications (e.g. Roedder, 1984; Shepherd et al. 1985; Goldstein and Reynolds, 1994).

X-ray diffraction (XRD) analysis was performed on the clay fraction $(<2 \mu \mathrm{m})$ of samples of the Northaw Great Wood clay, and the matrix of the Upnor Formation pebble bed from borehole 404T in central London, grid reference TQ 33637960 Ellison et al. 2004). The clay fraction was separated by centrifugation and filtered onto unglazed ceramic tiles. The samples were scanned using a Siemens PSD X-ray diffractometer and Ni-filtered CuK $\alpha$ radiation. The clay tiles were scanned from 2 to $40^{\circ} 2 \theta$ using a $0.02^{\circ}$ step width and $0.2 \mathrm{~mm}$ slits. The tiles was scanned again after treating with glycol, after heating at $400^{\circ} \mathrm{C}$ for 4 hours, and after heating at $550^{\circ} \mathrm{C}$, also for 4 hours. Powder diffraction XRD was performed on the cryptocrystalline cement from the Bradenham sample, to determine the form of silica present.

\section{RESULTS}

\subsection{Petrography}

The HPS comprises flint pebbles, derived from the Chalk, quartz sand from a variety of sources, and quartz cement, plus $<5 \% \mathrm{Ti}$ oxides, clay, iron oxides and feldspar. The Bradenham Coppice sample is predominantly saccharoid type silcrete, with optically continuous quartz overgrowths and subsidiary microquartz and/or cryptocrystalline quartz cements (Figure 3A). The Chesham sample (Figure $3 \mathrm{~B}$ ) is purely saccharoid type silcrete with a grainsupported (GS-) fabric (sensu Summerfield, 1983). The Ley Hill sample (Figure $3 \mathrm{C}$ ) is of the type described as "extremely hard", with cryptocrystalline silica or microquartz cements dominant, either within a GS- or floating (F-) fabric (Summerfield and Goudie, 1980). The Northaw Great Wood sample (Figure 3D, Figure 4A) has cement that is so intensely ferruginised (through infiltration, or precipitation of iron oxides and clay) that only occasional small patches of cryptocrystalline quartz are visible optically, indicating that this GSto F-fabric sample is probably of the "extremely hard" type. The Puckeridge sample (Figure 3E) is purely saccharoid type silcrete with a grain-supported (GS-) fabric. The Ley Hill and Bradenham Coppice are breccioconglomerates, i.e. they contain angular as well as rounded pebble fragments (Ullyott and Nash, 2006). The clay-rich sediment enclosing the Northaw Great Wood puddingstone is a poorly sorted sandy silty clay (Figure 5) with a low organic content and $\sim 3 \%$ ragged, silt-size, detrital Ti oxides. The clay mineral assemblage of this sediment is dominated by illite-smectite, plus illite, and small amounts of kaolinite and chlorite (Figure 6).

Visual estimates from thin section indicate that quartz constitutes $>95 \%$ of the HPS, with the remainder comprising $\mathrm{K}$ feldspar, rutile, zircon, tourmaline, iron 
oxides and clay minerals; traces of anatase and pseudobrookite have also been identified by micro-XRD (Ullyott et al. 2015). Petrographic textures vary on a centimetre scale, and it should be remembered that a $5.1 \times 2.5 \mathrm{~cm}$ thin section might not be wholly representative of a $2 \times 1 \mathrm{~m}$ puddingstone block.

Pebbles and cobbles are all flint; many pebbles have rims that are visible using optical petrography; these rims appear darker or paler than the core of the pebbles. Breaks, fractures and pits in pebbles cut across these rims and are infilled with sandy matrix (Figure 4B), indicating that the colour zonation is not diagenetic, and may be a result of weathering prior to fracturing, and prior to deposition in the pebble bed. SEM EDS chemical analysis reveals no detectable difference between the rims and cores, even in samples where the pebbles have a red or orange coating. This implies that any iron oxide layer is too thin, or the concentration of iron is too low, to be detected by this means.

The sand-size particles in the matrix are predominantly monocrystalline quartz, plus rare $\mathrm{K}$ feldspar and heavy minerals. Grain-size and sorting vary (Table 1) but the sand is predominantly well sorted, and has a very fine to medium grain size. $C L$ images show that the grains have a range of luminescence colours from blue to red (Figures 7A-C). The predominance of red colouration in Figure 5B may be a consequence of a higher electron dosage due to the magnification being higher than in the other CL images. Lower magnification images (not shown) of this sample do not show such a predominance of red CL. This does not detract from interpretation of cement textures. The loose material from the surface of an exposed puddingstone boulder of the Colliers End outlier comprises loose grains and aggregates of particles that vary from silt-size to very fine sand-size. These grains are typically sub-rounded and moderately sorted monocrystalline quartz, with $<1 \%$ zircon and Ti oxide minerals. They are therefore very similar to the matrix sand composition of the HPS, and we conclude that they are derived from the HPS boulder on which they were found.

"Caps" on pebbles formed by infiltration of sediment prior to cementation (Ullyott et al. 2015) are present in the Ley Hill (Figure 4C), Bradenham Coppice and Puckeridge samples. If they are present in the Northaw Great Wood sample they are concealed by the ferruginisation. The caps are typically a few mm long and comprise quartz silt, microcrystalline Ti oxides and traces of unidentified clay, and are cemented by microquartz (individual crystals visible in thin section) and cryptocrystalline quartz (individual crystals not identifiable in thin section). Ti oxides occur as microcrystalline aggregates and silt-sized, sometimes corroded, grains throughout the HPS but are most common, particularly the microcrystalline particles, in caps. In a small, incompletely cemented part of the Bradenham Coppice sample iron oxides have precipitated in pores after microcrystalline quartz cementation, and may also have replaced the microquartz (Figure 8 ). The orange colour in hand specimen suggests that the oxides are goethite.

Silica cement occurs in a variety of forms, as illustrated in Figures 7 and 9. Silica cement is present as macroquartz overgrowths, microquartz and cryptocrystalline quartz, with two and sometimes all three varieties occurring in the same sample, notably in the Bradenham Coppice sample (Figures 7C \& 9A). Macro-quartz cementation is syntaxial and was apparently limited to 
clay and silt-free intergranular porosity, as there is a strong correlation between silt-rich matrix and cryptocrystalline quartz cement. In the Bradenham Coppice sample the macroquartz has an irregular boundary with some of the flint pebbles, implying that the cement has replaced the margins of the pebbles (Figure 9B). The Chesham and Puckeridge samples have macro-quartz over growth cement (Figures 9A-B) that is zoned in CL images. An early non-luminescent cement is followed by a red-luminescent cement; both of these zones contain finer scale zoning within them. The finer scale zonation is more pronounced in the Chesham than in the Puckeridge cement. The Northaw Wood, Ley Hill and Bradenham samples have predominantly cryptocrystalline quartz cement (Figures 7C-D, 8, \& 9A) that cannot be resolved in $\mathrm{CL}$ images. In the Bradenham Coppice sample macro-quartz only occurs cementing micro-fractures that cross grains and cemented sand (Figure 7D).

\subsection{Stable isotope analysis}

The $\delta^{18} \mathrm{O}$ results for the Bradenham Coppice silica samples range from +17.6 to $+33.1 \%$ o (Table 2 ). The results are strongly bimodal, with separates consisting of quartz cement, having much lower $\delta^{18} \mathrm{O}(+17.6$ to $+21.8 \%$ o $)$ than separates composed of flint pebbles or fragments $(+28.6$ to $+33.1 \%$ ).

\subsection{Fluid inclusion analysis}

Despite extensive searching, the few inclusions in the quartz cement (Figure 10) were unreactive to microthermometry. Some may contain air and some single-phase liquid water, but without the microthermometry this remains unclear. In addition, the exact boundary between grains and overgrowths was frequently unclear due to the absence of a dust rim.

\subsection{X-ray diffraction}

The two clay XRD analyses show both samples to be dominated by swelling clay (smectite) and illite, with more smectite present in the Upnor Formation sample. The Northaw Wood clay contains more kaolinite than is present in the Upnor Formation sample.

\section{DISCUSSION}

\subsection{Detrital quartz}

The observed colour zonation in flint pebble margins pre-dates pebble fracturing, deposition and silicification, and is indicative of weathering. Pebble fracturing occurred both prior to deposition, and after. Variable proportions of sand grains have been fractured before deposition. The angularity of these grains, and of flint pebbles, suggests that the fracturing occurred not long before, or during, formation of the pebble bed. This is consistent with the 
inferred shallow-marginal marine origin of the Upnor Formation (Ellison et al. 2004). The size and composition of the pebbles in the five HPS samples is consistent with Hertfordshire Puddingstone comprising leached and silicified pebble beds of the Upnor Formation, as previously suggested (Small, 1980; Young and Lake, 1988; Lovell and Tubb, 2006; Aldiss, 2012; Lovell, 2015).

$\mathrm{CL}$ images of the cemented sand indicate a range of quartz colours, consistent with more than one source (Figure 7A \& B). The loose sand has mineralogical and grain characteristics consistent with derivation through recent weathering of the puddingstone sample from which it was collected.

\subsection{Quartz cement}

The distribution of quartz cement type is controlled by the nature of the host material, consistent with the observations of Webb and Golding (1998); macroquartz occurs in macropores, and micro-quartz and cryptocrystalline quartz occurs in clay and silt matrix. CL banding of the macroquartz cement in the Puckeridge and Chesham samples implies variation in the trace element composition of the quartz, due to fluctuations in the chemistry of the pore water from which the cement precipitated. Banding is only visible in the macroquartz cement, and not in the cryptocrystalline variety. Further research is needed to establish whether it is a feature of all macroquartz cemented HPS in the London Basin, and whether the bright and dark zones show a regional distribution. Silcrete of a similar age from the South Downs (Ullyott et al. 2015) has un-zoned, non-luminescent macroquartz cement implying that pore fluid composition does not inevitably fluctuate. The absence of dust rims is unusual, and may be a consequence of leaching prior to silicification.

There are at least three potential sources of silica for cementation in silcrete:

(1) Leaching in acidic weathering environments. This would result in the rapid decomposition of clay and feldspar, releasing a variety of solutes including silica (Thiry, 1999). This mechanism has the potential to produce large volumes of dissolved silica that could cement adjacent pebble beds in a pedogenic environment. If the pebble bed was buried at the time of silicification, a mechanism is required to move the solution down through the sediment, without precipitating the silica before it reaches the pebble bed.

(2) Replacement of quartz, particularly by calcite, in the form of calcrete. Flint pebbles from pebble beds in the Lambeth Group have apparently been corroded and shattered by formation of calcrete nodules (Jackie Skipper, pers.comm.). There is no evidence however to suggest this has been more than a localised mechanism for dissolved silica generation, as the nodules are not widespread.

(3) Quartz dust produced through grain abrasion in arid and semi-arid environments. Having a high surface area this form of silica is readily soluble. This mode of origin is considered significant only in desert environments (Waugh, 1970). If silica generated by this means did enter into solution, it cannot have made more than a very minor contribution to the total silica cement, because the HPS did not form in a desert. 
The origin of the silica in silcrete has been extensively discussed in the literature (Beckwith and Reeve, 1964; Thiry et al. 1988; Wilmott and Young, 1985; Ullyott et al. 2004; Ullyott and Nash, 2006). Silcrete formation is restricted to warm, arid climates (Summerfield, 1983; 1986), which implies that enhanced silica solubility at elevated temperatures and under conditions of high evaporation are major factors driving silica precipitation close to the Earth's surface. In general temperature changes are likely to be far more rapid than the response of silica to supersaturation, which is so slow that surface waters are commonly supersaturated with respect to quartz (Siever, 1962).

The consensus for the UK Palaeogene silcretes is that dissolution of clays is the principal source of silica (Wilmott and Young, 1985; Ullyott et al. 2004; Ullyott and Nash, 2006). Leaching would have provided a sufficient source of silica for the cement, and also contributed Ti for a proportion of the authigenic Ti oxides present in the HPS. If a supersaturated solution remains static for sufficient time, then quartz can precipitate (Siever, 1962). However, in a surface or near surface environment, with elevated temperatures (causing increased silica solubility) such as characterised the PETM, evaporation would have been the most likely driver of silica precipitation. The zoning observed in CL images may be interpreted to indicate quartz cement growth during fluctuations in the water table. This is consistent with shallow burial cementation from groundwater silica. Quartz cementation at elevated nearsurface temperatures during the PETM could have occurred during pedogenesis of the Reading Formation, which overlies the Upnor Formation. A pedogenic origin for silcrete in the Upnor Formation, however, is difficult to demonstrate, due to the lack of pedogenic textures; a shallow burial origin is considered, using criteria listed in Nash and Ullyott (2016, this volume) more probable.

\subsection{Clay mineralogy of potential host sediment}

The clay assemblages of the Northaw Great Wood and the Upnor Formation pebble bed samples contain the same clay minerals, but in different relative proportions. The variability of the clay assemblages of the Upnor and Reading formations (Huggett and Knox, 2006) is much greater than the difference between these two samples. Our data is therefore consistent with the HPS having formed in Upnor Formation pebble beds, but it is not proof.

\subsection{Ferruginisation}

The addition of iron oxides to the silcrete, such as observed for the Northaw Great Wood sample, may have occurred after deposition of the sediment but before silica cementation, though the cryptocrystalline nature of both cements precludes verification of this possibility. In the Bradenham Coppice sample iron oxides post-date quartz cementation because they have precipitated in pores incompletely cemented by quartz, and the iron oxides may also have replaced the microquartz (Figure 8 ). 


\subsection{Oxygen isotopes}

The highest $\delta^{18} \mathrm{O}(+33.1 \%)$ obtained for puddingstone flint suggests precipitation at $25-26^{\circ} \mathrm{C}$, assuming a Late Cretaceous oxygen isotopic composition for seawater (-1\%; Shackleton and Kennett, 1975; Zeebe, 2001), and using the oxygen-isotope quartz-water geothermometer of Matsuhisa et al. (1979). This result is consistent with derivation of these pebbles from flint formed in the Upper Cretaceous Chalk Group of southern England. The range to lower flint $\delta^{18} \mathrm{O}$ may indicate lower local seawater $\delta^{18} \mathrm{O}$ resulting from freshwater input, post-formation alteration, and (or) undetected infiltration or contamination by silica cement.

The oxygen isotopic results for the puddingstone silica cement can be used to estimate its temperature of formation. This calculation first requires an estimate of the oxygen isotopic composition of the water $\left(\delta^{18} \mathrm{O}_{\text {water }}\right)$ involved in cementation. Slightly later in the early Ypresian, Zacke et al. (2009) have reported very low phosphate oxygen isotopic compositions for marine shark tooth enameloid from this region, which they interpret to indicate substantial freshwater dilution of the North Sea by fluvial discharge from the East Shetland Platform and Scottish Highlands (Collinson et al. 1985; Coward et al. 2003). The increased meteoric runoff from the north accompanied the upward spike in temperature associated with the PETM (Charles et al. 2011). Zacke et al. (2009) suggested $\delta^{18} \mathrm{O}$ of -18 to $-13 \%$ for this freshwater, based on terrestrial plant $n$-alkane hydrogen isotopic compositions reported by Pagani et al. (2006).

Using the average silica cement oxygen isotopic composition $(+18.7 \%)$ and the geothermometer of Matsuhisa et al. (1979), calculated temperatures for silica cementation range from $16^{\circ} \mathrm{C}\left(\delta^{18} \mathrm{O}_{\text {water }}=-18 \%\right)$ to $36^{\circ} \mathrm{C}\left(\delta^{18} \mathrm{O}_{\text {water }}=-\right.$ $13 \%$ ). Temperatures towards the higher part of this range are more probable when one considers: (i) evaporative ${ }^{18} \mathrm{O}$-enrichment of meteoric runoff under warm, arid conditions, (ii) the generally very warm Earth temperatures at this time, especially during the PETM (Zachos et al. 2001), and (iii) potential contamination of the silica cement separates by ${ }^{18} \mathrm{O}$-rich flint, which would artificially increase the size of the mineral-water oxygen isotopic fractionation and thus lower the calculated temperature. Identification of the timing of silica cementation is essential to determining whether evaporative ${ }^{18} \mathrm{O}$-enrichment of meteoric runoff contributed to the oxygen isotopic composition of the silica cement. Surface evaporation is not consistent with sub-surface silicification, as silica would have been precipitated prior to sediment burial.

A further consideration is that some of the measured variation in silica $\delta^{18} \mathrm{O}$ reflects a complex history of silcrete formation, as is evident petrographically (Figures 7A-B). The multiple generations of silica cementation almost certainly would have involved a range of temperature and $\delta^{18} \mathrm{O}_{\text {water }}$. Notwithstanding this complexity, the oxygen isotopic compositions of the silica cement strongly support silcrete formation from meteoric ground waters similar to those likely to have been present during the PETM in this region.

\section{CONCLUSIONS}


HPS comprises flint pebbles derived from the Chalk, sand from a variety of sources and quartz cement, plus $<5 \%$ Ti oxides, clay, iron oxides and feldspar. Variable amounts of flint and sand grains have been fractured before deposition. The angularity of these grains suggests that the fracturing occurred not long before formation of the pebble bed. Weathering zonation in the outer rims of flint pebbles predates fracturing, which is consistent with fracturing being relatively late in the sequence of events. The loose sand found on boulders of exposed puddingstone is derived from the matrix of the puddingstone. The implication is that the quartz cement has weathered; this process is more likely to affect cryptocrystalline quartz than macroquartz, due to the much larger surface area of the former that is exposed to weathering. Despite being overall very resistant to weathering, some boulders are therefore prone to dissolution of cement by rainwater.

The range of matrix fabrics, from macro-, to micro- to cryptocrystalline quartz, is consistent with varying conditions under which cementation occurred. Further work is required to determine what these conditions may have been. The macroquartz cement grew as syntaxial overgrowths on sand grains and shows zonation in CL images, beginning with non-luminescent quartz, developing into predominantly red-luminescent zones as the crystals grew and filled the pore space. This zonation indicates that either the porewater composition fluctuated, or that there were breaks in precipitation. Either interpretation is consistent with shallow burial silcretisation. Ferruginisation occurred after silicification, and infilled remaining porosity and microporosity associated with the quartz cement and possibly also replaced quartz cement. The origin oxides may be derived through illuviation; their presence indicates continued fluid movement through the HPS after cementation.

The source of the silica remains unclear, but leaching of feldspar, and clayrich sediment in acidic weathering environments is the most likely mechanism for producing sufficient dissolved silica. As proposed previously for the UK Tertiary silcretes (Wilmott and Young, 1985; Ullyott et al. 2004; Ullyott and Nash, 2006), it is probable that the silica was derived both internally, within the pebble bed, and from adjacent clay-rich sediment. Although Lambeth Group clay assemblages are too diverse to identify precisely the clay-rich beds with which the puddingstones are associated, the composition of the Northaw Great Wood clay is consistent with it being Upnor Formation. The oxygen isotope data for the silica cement are consistent with silcrete formation from highlands-derived, low- ${ }^{18} \mathrm{O}$ meteoric groundwater at warm near-surface temperatures. This is consistent with the very warm Earth temperatures experienced at this time, especially during the PETM.

\section{REFERENCES}

Aldiss, D.T. 2012. The stratigraphical framework for the Palaeogene successions of the London Basin, UK. Open Report OR/12/004, British Geological Survey, Keyworth, Nottingham. pp. 95.

Beckwith, R.S. and Reeve, R. 1964. Studies on soluble silica I soils. II. The release of monosilicic acid from soils. Australian Journal of Soil Research 2, 23-45. 
Catt, J.A. and Doyle, J. 2010. The Palaeogene. In: Catt, J.A. (Ed.), Hertfordshire Geology and Landscape. Hertfordshire Natural History Society. Welwyn Garden City. pp. 384.

Clayton, R.N. and Mayeda, T.K. 1963. The use of bromine pentafluoride in the extraction of oxygen from oxides and silicates for isotopic analysis. Geochimica et Cosmochimica Acta 27, 43-52.

Charles, A.J., Condon, D.J., Harding, I.C., Pälike, H., Marshall, J.E.A, Cui, Y., Kump, L. and Croudace, I.W. 2011. Constraints on the numerical age of the Paleocene-Eocene boundary. Geochemistry Geophysics Geosystems 12, 1-19.

Collinson, M.E., Batten, D.J., Scott, A.C., and Ayonghe, S.N. 1985. Palaeozoic, Mesozoic and contemporaneous megaspores from the Tertiary of southern England; indicators of sedimentary provenance and ancient vegetation. Journal of the Geological Society (London) $142,375-395$.

Coward, M.P., Dewey, J., Hempton, M. and Holroy, J. 2003. Tectonic evolution. In: Evans, D., Graham, C., Armour, A., and Bathurst, P. (Eds.), The Millennium Atlas: Petroleum Geology of the Central and Northern North Sea. Geological Society (London), 17-33.

Ellison, R.A., Woods, M.A., Allen, D.J., Forster, A., Pharoah, T.C. and King, C. (2004) Geology of London; special memoir for 1:50 000 geological sheets 256 (north London, 257 (Romford), 270 (south London) and 271 (Dartford) (England and Wales) Memoir of the British Geological Survey. 114 pp.

Entwistle, D.C., Hobbs, P.R.N., Northmore, K.J., Skipper, J., Raines, M.R., Self, S.J., Ellison, R.A., and Jones, L.D., 2013. Engineering geology of British rocks and soils - Lambeth Group. Engineering Geology Directorate Open Report OR/13/006. British Geological Survey. HMSO. London. 316 pp.

Goldstein, R.H. and Reynolds, T.J. 1994. Systematics of fluid inclusions in diagenetic minerals. S.E.P.M. Short Course 31, 199 Pp.

Huggett, J.M. and Knox, R.W.O'B. (2006) Clay mineralogy of the Tertiary onshore and offshore strata of the British Isles. In: Jeans. C.V. and Merriman, R.J. (Eds.), Clay Minerals in Onshore and Offshore Strata of the British Isles, 5-46.

Knox, R.W.O'B., 1996. Tectonic controls on sequence developments in the Palaeocene and earliest Eocene of southeast England: implications for North Sea stratigraphy. In: Hesselbo, S.P. and Parkinson, D.N. (Eds.), Sequence Stratigraphy in British Geology: Geological Society (London) Special Publication 103, 209-230.

Leng, M.J. and Sloane, H.J. 2008. Combined oxygen and silicon isotope analysis of biogenic silica. Journal of Quaternary Science 23, 313-319.

Lourens, L. Hilgen, F., Shackleton, N.J., Laskar, and J. Wilson, D. 2004. The Neogene Period, In: Gradstein, F. Ogg, J., and Smith, A. (Eds.), A 
geologic time scale 2004. Cambridge (UK): Cambridge University Press, pp. 409-440.

Lovell, B. and Tubb, J. 2006. Ancient quarrying of rare in situ Palaeogene, Hertfordshire Puddingstone, Mercian Geologist 16, 185-189.

Lovell, B. 2015. Palaeogene silcretes and the 55 Ma global warming event: is there proof in the Hertfordshire Puddingstone? This issue.

Matsuhisa,Y., Goldsmith, J.R., and Clayton, R.N. 1979. Oxygen isotopic fractionation in the system quartz-albite-anorthite-water. Geochimica et Cosmochimica Acta 43, 1131-1140.

Milnes, A.R. and Thiry, M. 1992. Silcretes. In: Martini, I.P. and Chesworth, W. (Eds.), Developments in Earth Surface Processes 2: Weathering, Soils and Palaeosols, Elsevier, Amsterdam. Pp. 349-377.

Moffat, A.J. and Catt, J.A. 1983. A new excavation in Plio-Pleistocene deposits at Little Heath. Transactions of the Hertfordshire Natural History Society 29, 5-10.

Pagani, M., Pedentchouk, N., Huber, M., Sluijis, A. Schouten, S., Brinkhuis, H., Dickens, G.R. 2006. Arctic hydrology during global warming at the Palaeocene/Eocene thermal maximum. Nature 442, 671-675.

Page, D. and Skipper, J. 2000. Lithological characteristics of the Lambeth Group. Ground Engineering 33, 38-43.

Robinson, E. 1994. Hertfordshire Puddingstone foray, Saturday 5 June, 1993. Proceedings of the Geologists' Association 105, 77-79.

Roedder, E. 1984. Fluid inclusions. Mineralogical Society of America. Reviews in Mineralogy 12, $644 \mathrm{p}$.

Röhl, U., Westerhold, T., Bralower, T.J., and Zachos, J.C. 2007. On the duration of the Paleocene-Eocene thermal Maximum (PETM). Geochemistry Geophysics Geosystems 8, 1-13.

Shackleton, N.P. and Kennett, J.P. 1975. Late Cenozoic oxygen and carbon isotope changes at DSDP site 284: implications for glacial history of the Northern Hemisphere. In: J.P. Kennett, R.E. Houtz et al. (Eds), Initial Reports of the Deep Sea Drilling Project 29, pp. 801-807.

Shepherd, T.J., Rankin, A.H., and Alderton, D.H.M. 1985. A Practical Guide to Fluid Inclusion Studies, Blackie, pp. 239.

Siever, R. 1962 . Silica solubility, $0-200^{\circ} \mathrm{C}$., and the diagenesis of siliceous sediments. Journal of Geology 70,127-150

Small, R.J. 1980. The Tertiary geomorphological evolution of south-east England: an alternative interpretation. In: D.K.C. Jones (Ed.), The Shaping of Southern England. Academic Press, London, pp. 49-70.

Summerfield, M.A. ad Goudie, A.S. 1980. The sarsens of southern England: their palaeoenvironmental interpreation with reference to other silcretes. In: Jones, D.K.C. (Ed.) The Shaping of Southern England, Academic Press, London. pp. 71-100. 
Summerfield, M.A. 1983. Silcrete. In: Goudie, A.S. and Pye, K. (Eds.), Chemical Sediments and Geomorphology, Academic Press, London. Pp. 59-91.

Summerfield, M.A. 1986. Silcrete in the sedimentary record: identification, occurrence and palaeoenvironmental record (abstract). $12^{\text {th }}$ International Sedimentological Congress, Canberra, Abstracts, p. 290.

Thiry, M., Bertrand-Ayrault, M., Grisoni, J.-C., Menillet, F., and Schmitt, J.-M. 1988. Ground-water silicification and leaching in sands: example of the Fontainebleau Sand (Oligocene) in the Paris Basin, Bulletin of the Geological Society of America 100, 1283-1290.

Thiry, M., 1999. Diversity of continental silicification features: examples from the Cenozoic deposits in the Paris Basin and neighbouring basement. Special Publication of the International Association of Sedimentologists. 27, 87-127.

Thomas, E. and Shackleton, N.J. (1996) The Palaeocene-Eocene benthic foraminiferal extinction and stable isotope anomalies. In: Knox, R.W.O'B., Corfield, R.M. and Dunay, R.E. (Eds.), Correlation of the Early Palaeogene in Northwest Europe: Geological Society (London) Special Publication 101, 401-441.

Tubb, J. 2015. Palaeogene conglomerates (puddingstones) in the Colliers End Outlier East Hertfordshire, UK - evidence for silicification in the basal pebble bed of the Reading Formation. This issue.

Ullyott, J.S., Nash, D.J., and Shaw, P.A. 1998. Recent advances in silcrete research and their implications for the origin and palaeoenvironmental significance of sarsens. Proceedings of the Geologists' Association 109, 255-270.

Ullyott, J.S., Nash, D.J., Whiteman, C.A., and Mortimore, R.N. 2004.

Distribution, petrology and mode of development of silcretes (sarsens and puddingstones) on the eastern South Downs, UK. Earth Surface Processes and Landforms 29, 1509-1539.

Ullyott, J.S. and Nash, D.J., 2006. Micromorphology and geochemistry of groundwater silcretes in the eastern South Downs, UK. Sedimentology 53, 387-412.

Ullyott, J.S., Nash, D.J., and Huggett, J.M. 2015. Cap structures as diagnostic indicators of silcrete origin. Sedimentary Geology, 325, 119-131.

Waugh, B. 1970. Petrology, provenance and silica diagenesis of the Penrith sandstone (lower Permian) of northwest England. Journal of Sedimentary Research 40, 1226-1240.

Webb, J.A. and Golding, S.D. 1998. Geochemical mass-balance and oxygenisotope constrains on silcrete formation and its paleoclimatic implications in Southern Australia. Journal of Sedimentary Research 68, 981-993.

Wilmott, R.D. and Young, B. 1985. Aluminite and other minerals from Newhaven, Sussex: the first occurrence of nordstrandite in Great Britain. Proceedings of the Geologists Association 96, 47-52. 
Young, B., and Lake, R.D. 1988. Geology of the country around Brighton and Worthing. Memoir of the Geological Survey. HMSO, London, pp. 115.

Zachos, J., Pagani, M., Sloan, L., Thomas, E., and Billups, K. 2001. Trends, rythms and aberrations in global climate $65 \mathrm{Ma}$ to present. Science 292, 686-693.

Zacke, A., Voigt, S., Joachimski, M.M., Gale, A.S., Ward, D.J. and Tütken, T. 2009. Surface-water freshening and high-latitude river discharge in the Eocene North Sea. Journal of the Geological Society 166, 969-980.

Zeebe, R.E. 2001. Seawater $\mathrm{pH}$ and isotopic paleotemperatures of Cretaceous oceans. Palaeogeography, Palaeoclimatology, Palaeoeology $170,49-57$.

\section{Acknowledgements}

The Buckinghamshire samples were obtained from the collection of John Cooper (Bradenham Coppice and Ley Hill) at the Natural History Museum London and from Jackie Skipper (Chesham). The Hertfordshire samples were collected by Bryan Lovell (Puckeridge, and Colliers End sand) and by Diana Clements during a fieldtrip to Northaw Great Wood. We thank Norman Oxtoby at Royal Holloway for attempting microthermometry. We also thank Sam Russell at the Laboratory for Stable Isotope Science (LSIS), London, Canada, for assistance with flint and quartz separation and Andrea Prentice (LSIS) for assistance with the oxygen isotope analyses. Financial support for the mineral separation and oxygen isotope analyses was provided by the Natural Sciences and Engineering Research Council of Canada and also made possible in part through the Canada Research Chairs programme. The stable isotope infrastructure was funded by the Canada Foundation for Innovation and the Ontario Research Fund. This is LSIS Contribution \#336. Don Aldiss and Jean-Marc Baele are thanked for their helpful and constructive reviews.

Figures 


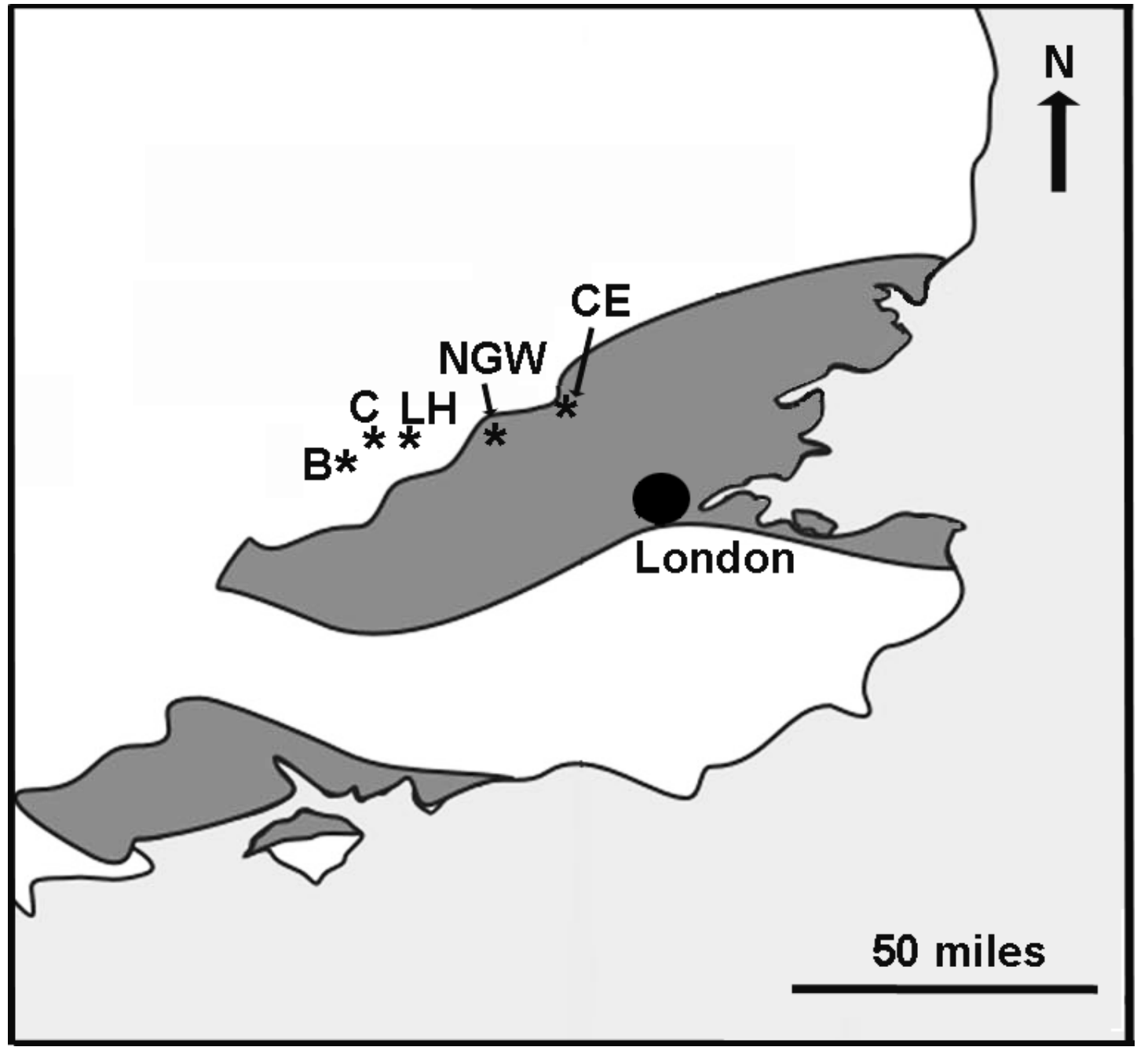

Figure 1. Map of South East England showing sample locations and the extent of Palaeogene deposits shown in grey. $\mathrm{B}=$ Bradenham, $\mathrm{C}=$ Cheshunt, $\mathrm{CE}=$ Colliers End, $\mathrm{LH}=$ Ley Hill, NHG $=$ Northaw Great Wood. 


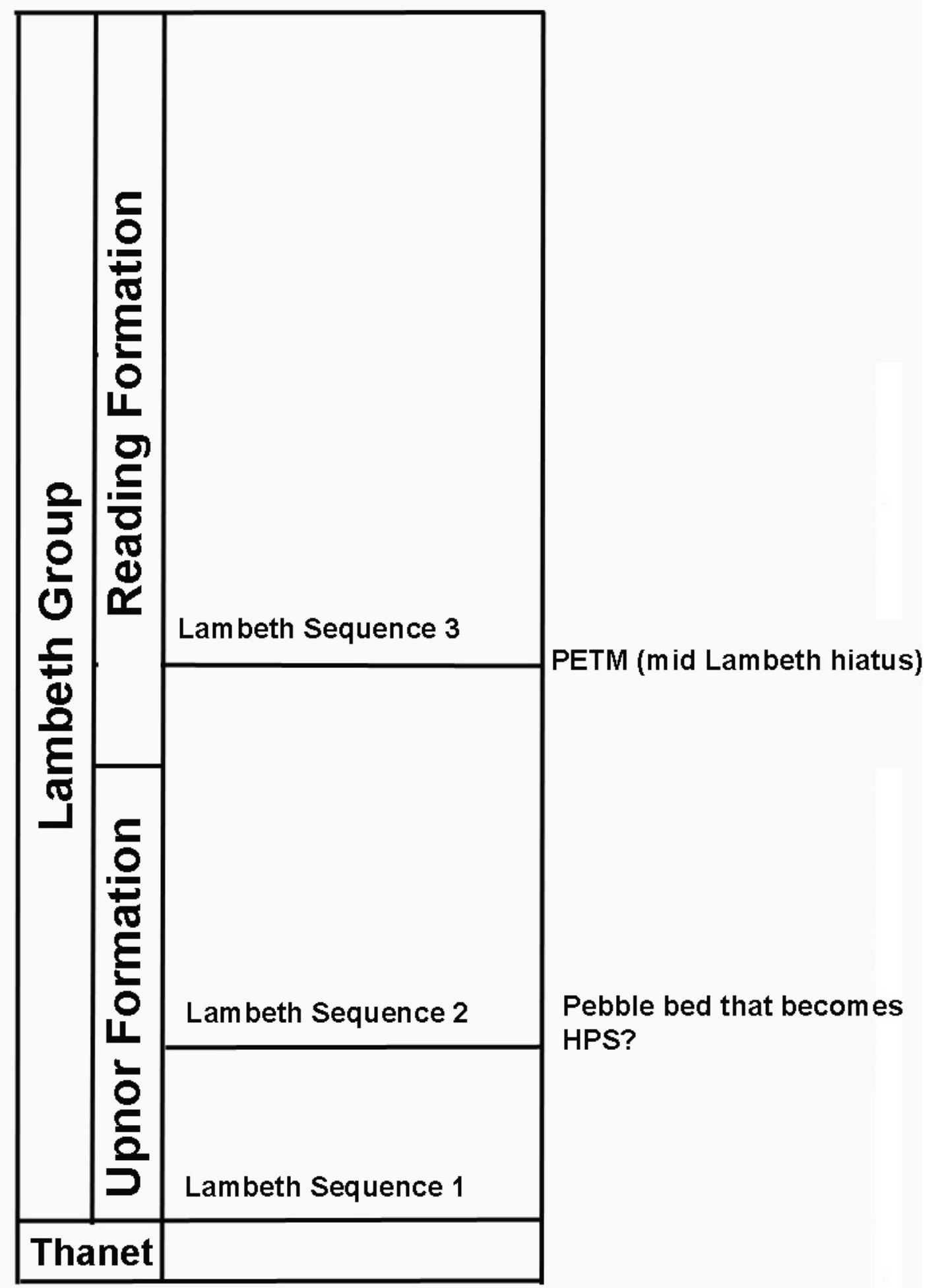

Figure 2. The HPS is here placed in the Upnor Formation at the base of the Lambeth-2 depositional sequence of Knox (1996. Silicification of the puddingstone concretions is here interpreted as taking place at the Paleocene- Eocene boundary, during the mid-Lambeth hiatus, that preceded the deposition of the Lambeth-3 (upper Reading-lower Woolwich) sequence. The depositional sequences follow the interpretation by Knox (1996) of the of the early Palaeogene succession of southeast England. PETM = PaleoceneEocene Thermal Maximum. 

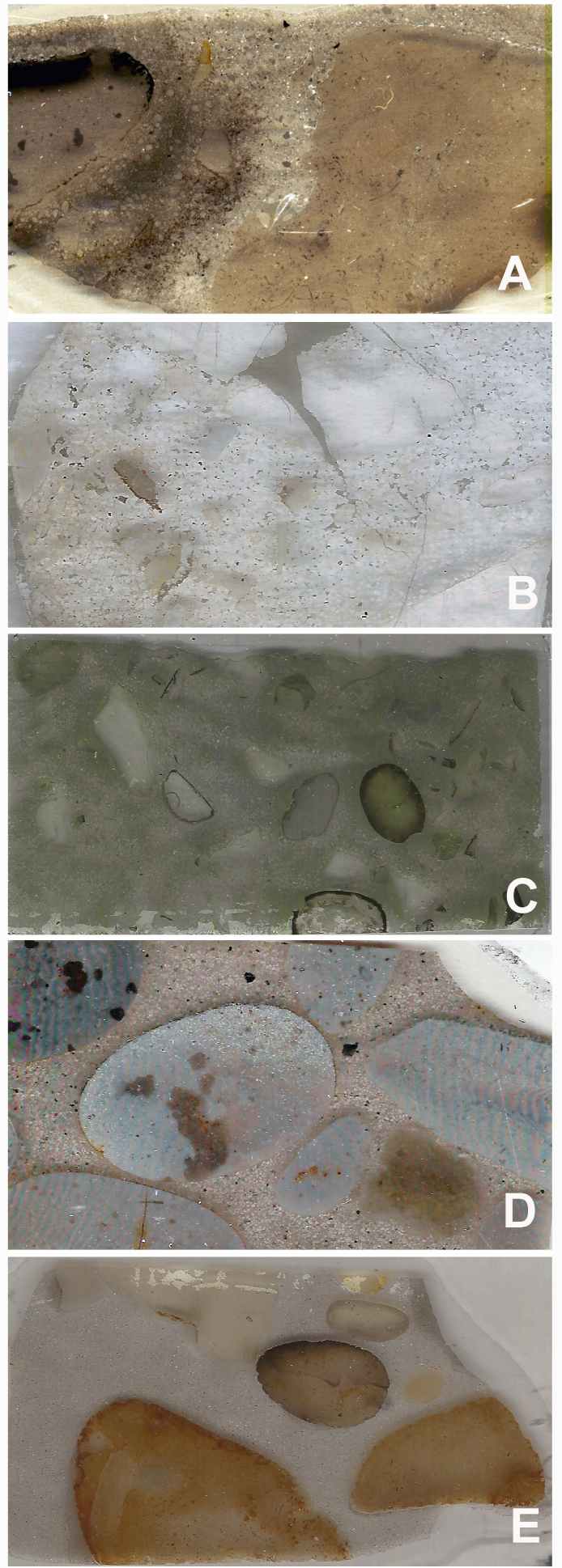

Figure 3. Scanned images of puddingstone thin sections. (A) Bradenham Coppice. (B) Chesham. (C) Ley Hill. (D) Northaw Great Wood. (E) Puckeridge. The horizontal field of view $=40 \mathrm{~mm}$ in all images. 


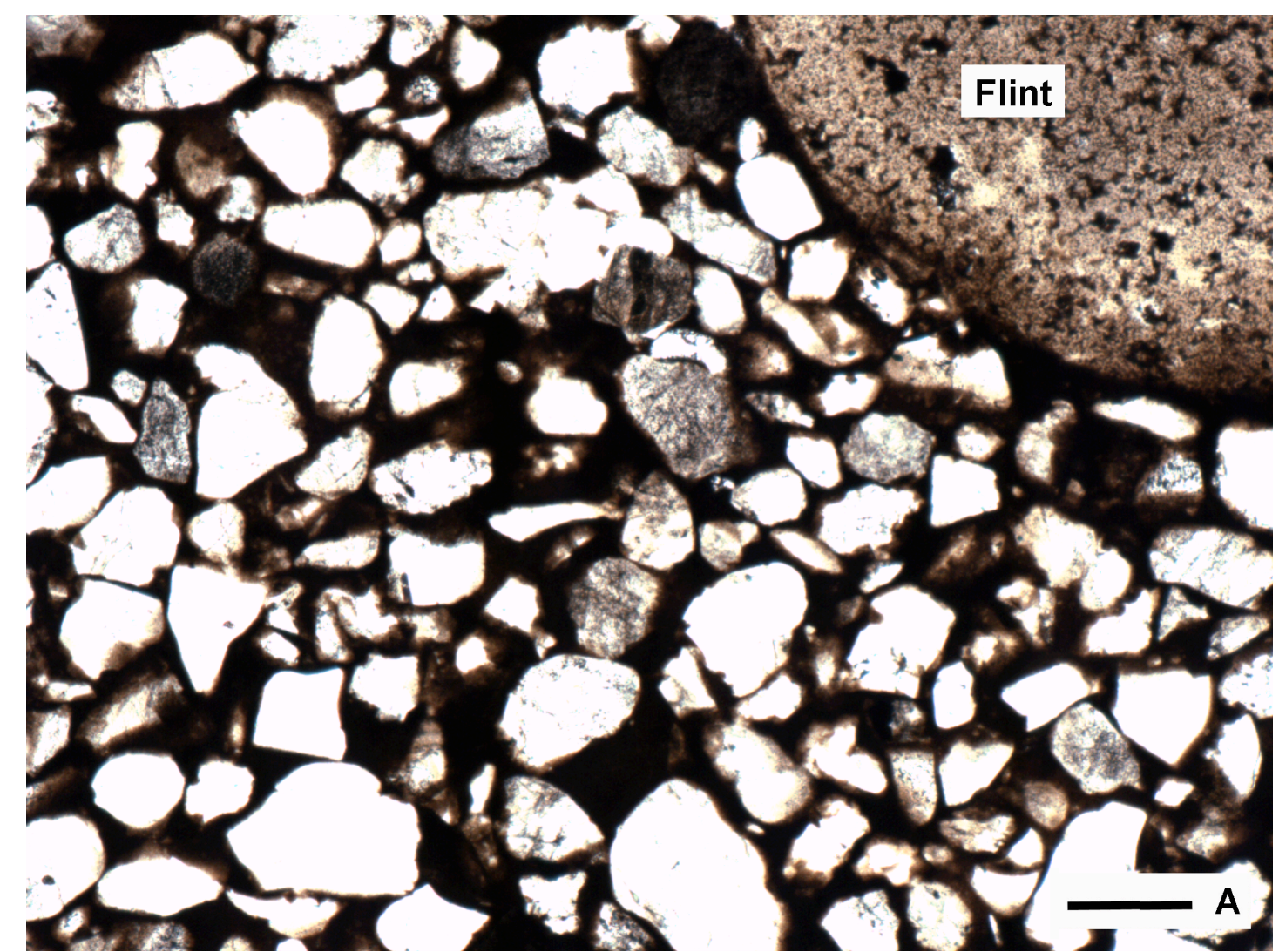

Figure 4. (A) Thin section micrograph of the Northaw Great Wood puddingstone, showing ferruginised cryptocrystalline quartz cement. Scale bar $=100 \mu \mathrm{m}$.

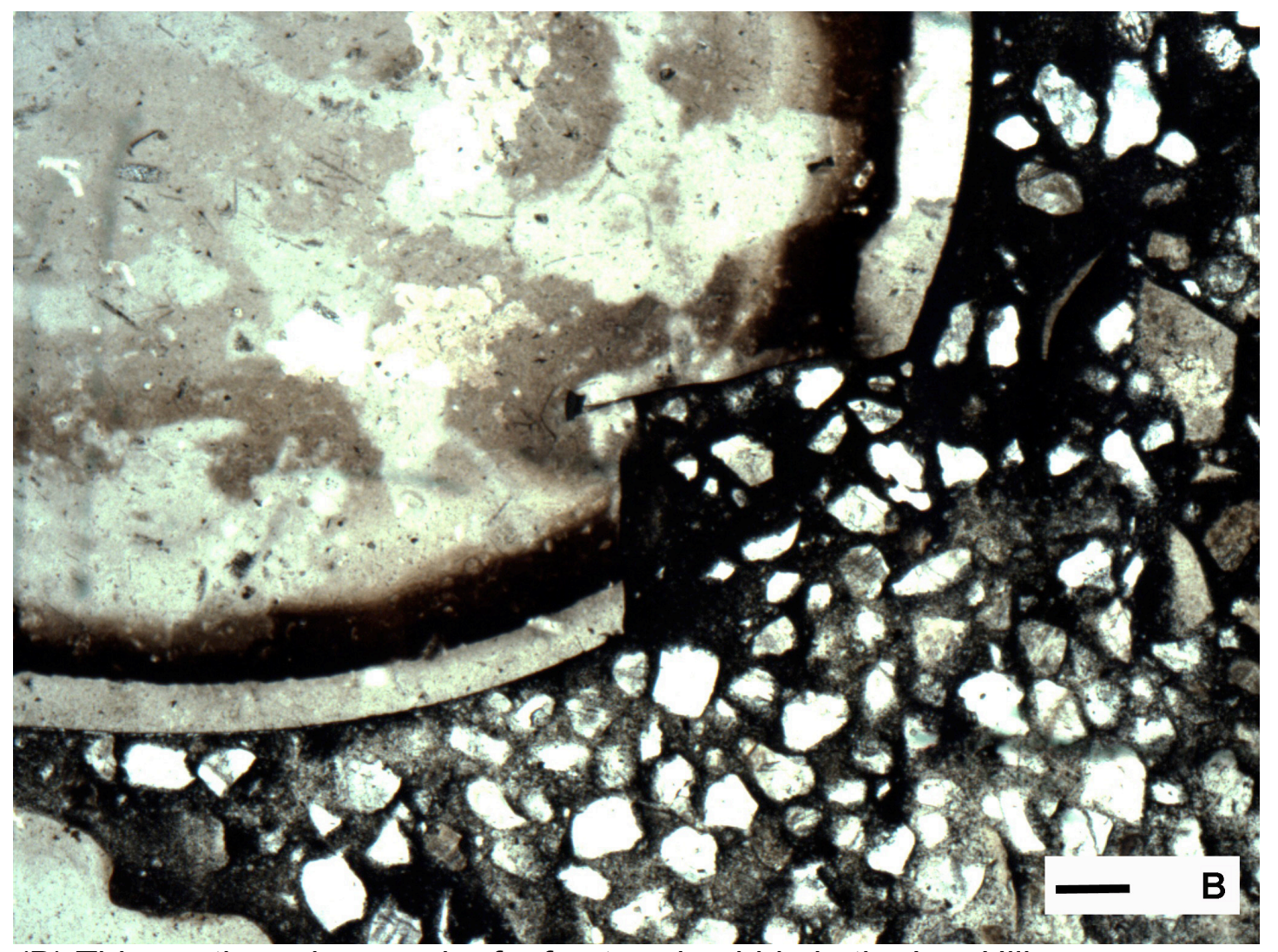

(B) Thin section micrograph of a fractured pebble in the Ley Hill puddingstone. The fracture cuts across the concentric colour rings and 
weathered outer zone of the pebble, indicating that weathering pre-dates fracturing. The sediment in-filling the crack indicates that weathering and fracturing pre-date sedimentation. Scale bar $=100 \mu \mathrm{m}$.

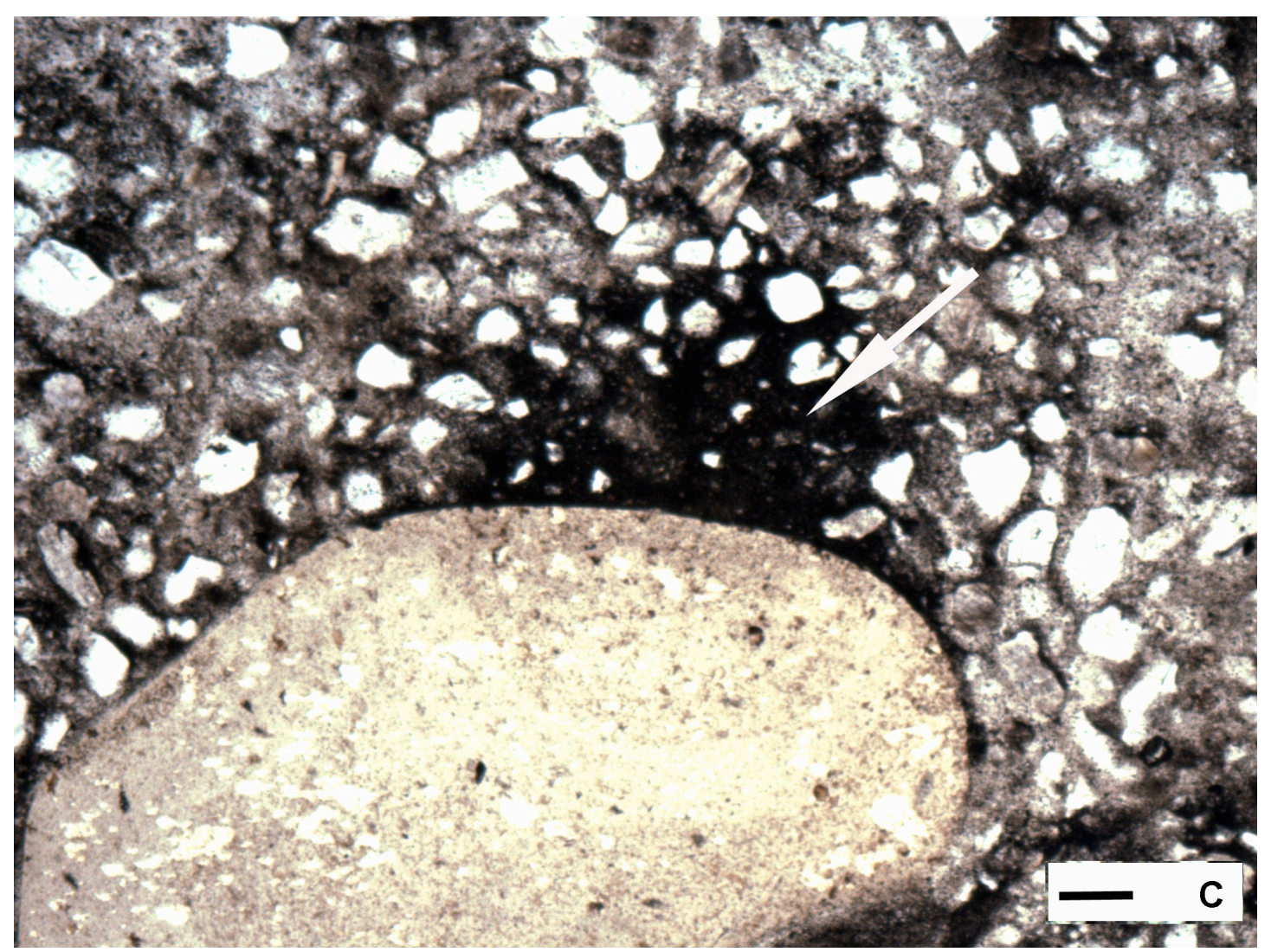

(C) Thin section micrograph of a cap (arrow) on a flint grain in the Ley Hill puddingstone. Scale bar $=100 \mu \mathrm{m}$. 


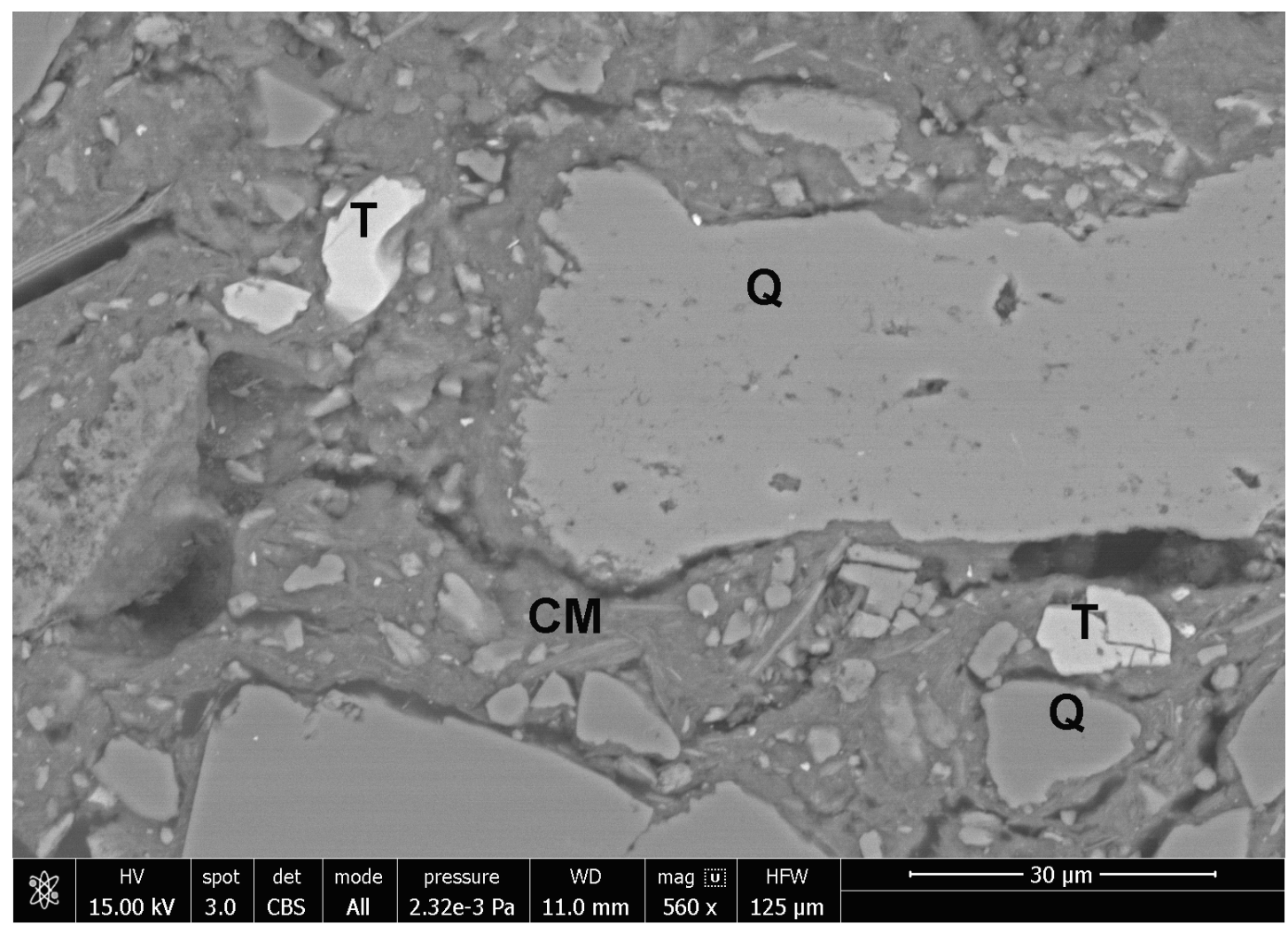

Figure 5. BSEM of the sandy silty clay that encloses the Northaw Great Wood puddingstone. The quartz $(Q)$ silt and sand is sub-angular to angular, and Tioxide minerals $(\mathrm{T})$ are widespread. $\mathrm{CM}=$ clay matrix. The sample is believed to be in situ; hence this sediment may represent the host for puddingstone formation. Scale bar $=30 \mu \mathrm{m}$. 

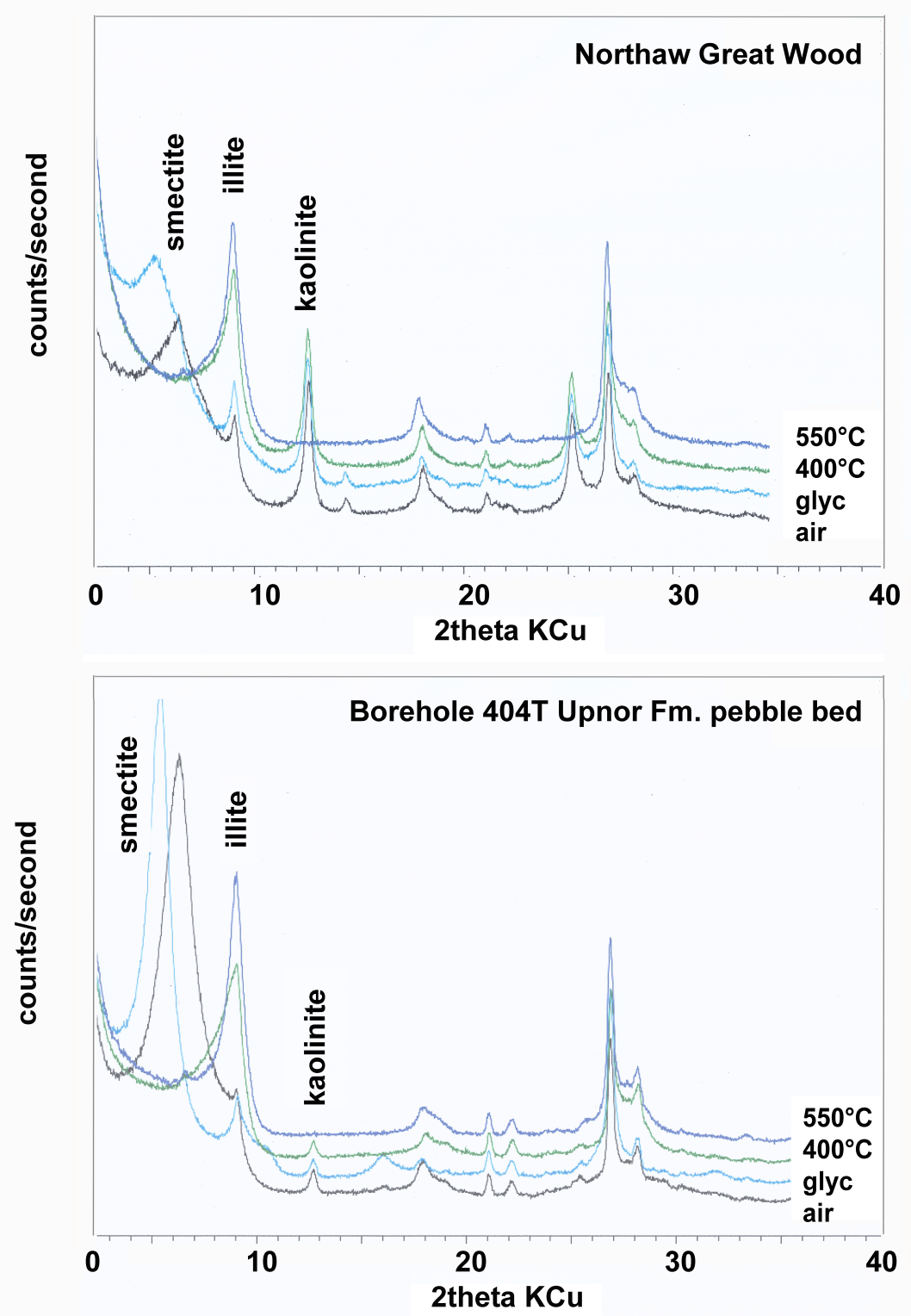

Figure 6. Overlaid XRD traces for air-dried, glycol solvated, and heated scans of the $<2 \mu \mathrm{m}$ fraction of the Northaw Great Wood clay sediment. 


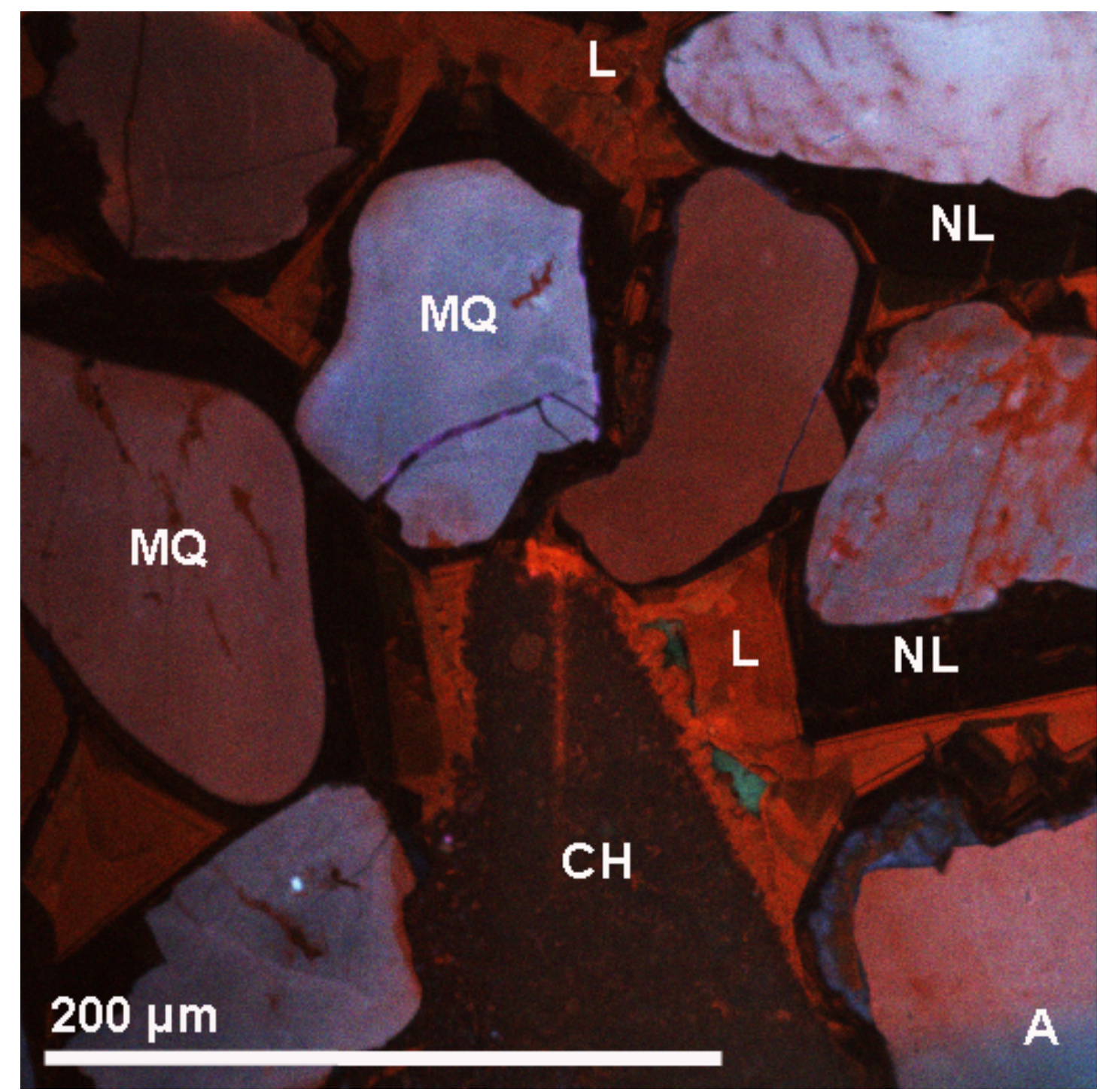

Figure 7. (A) Chrome CL image of the Chesham sample showing zonation in macroquartz cement. An early non-luminescent cement (NL) is followed by a red-luminescent cement $(L)$; both these zones have finer scale zoning within them. The range of luminescence colours of the monocrystalline quartz sand (MQS) indicates a varied provenance. $\mathrm{CH}=$ sand-size flint. Scale bar $=200$ $\mu \mathrm{m}$. 


\section{MQ}

\section{NL}

\section{$100 \mu \mathrm{m}$}

(B) Chrome CL image of the Puckeridge sample showing the same early nonluminescent, and later red luminescent zonation in macroquartz cement as is present in the Chesham sample. The finer scale zonation is more pronounced than in (A). The predominance of red luminescence may be due to a higher electron dosage than was used to acquire the other $C L$ images. Annotation is as in (A). Scale bar $=100 \mu \mathrm{m}$. 


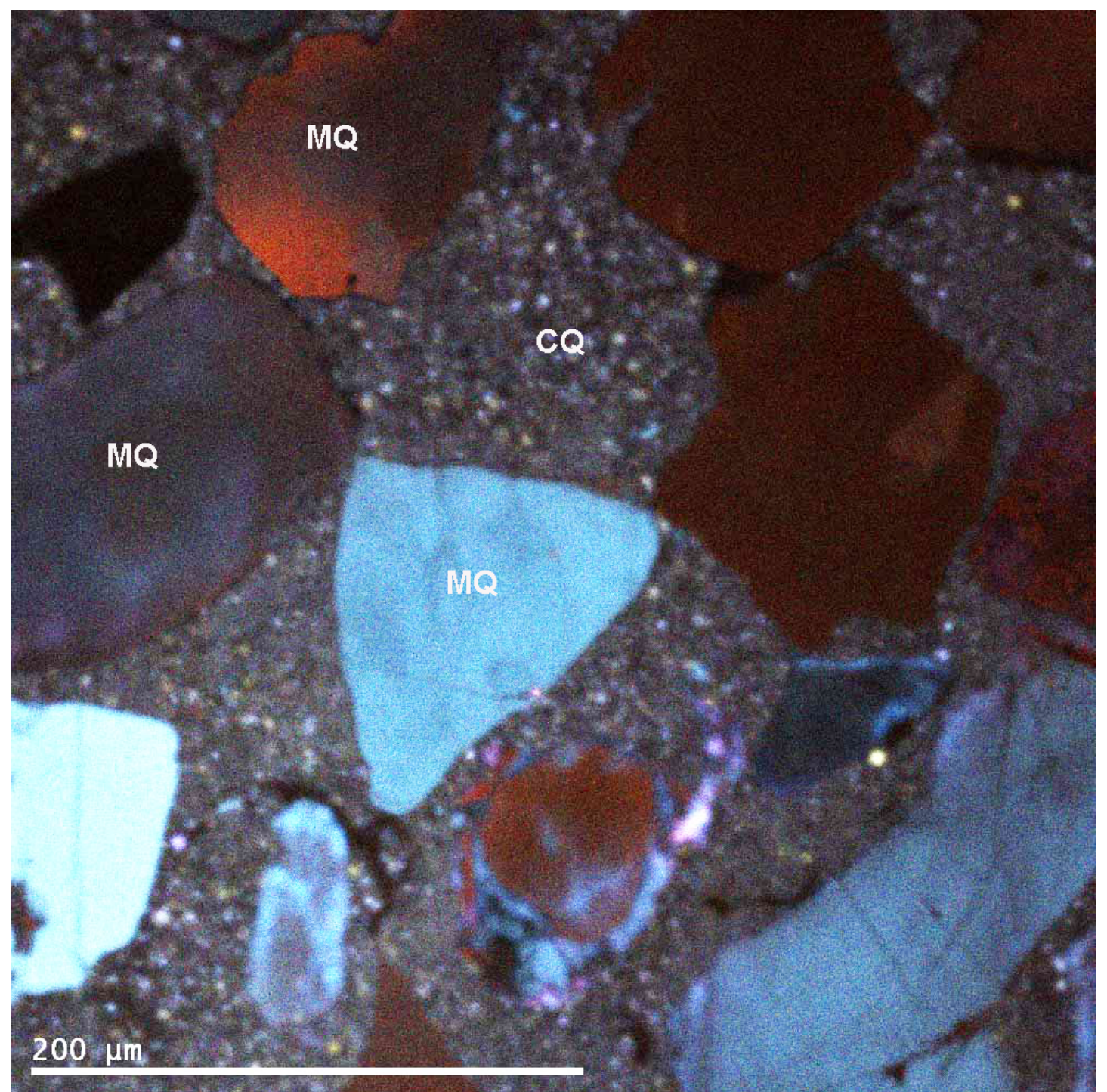

(C) Chrome CL image of the Bradenham Coppice sample showing cryptocrystalline quartz cement (CQ). The range of luminescence colours of the monocrystalline quartz sand (MQS) indicates a varied provenance. Scale bar $=200 \mu \mathrm{m}$. 


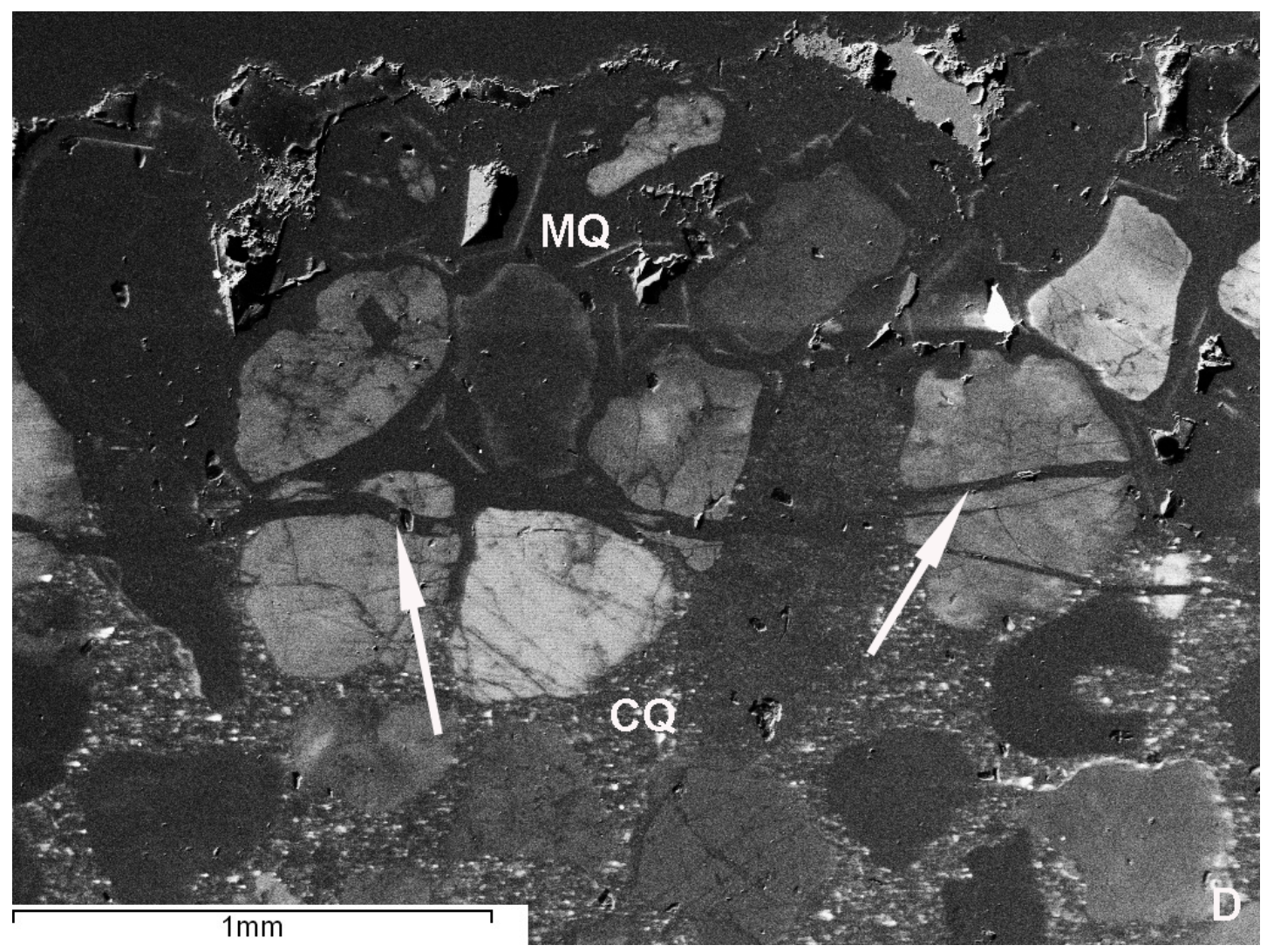

(D) Black and white CL image of the Bradenham Coppice sample showing macroquartz cement (MQ) cryptocrystalline quartz cement (CQ) and sand grains cross-cut by macroquartz cemented veins (arrows). At the top of the field of view the quartz cement is macroquartz. Scale bar $=1 \mathrm{~mm}$.

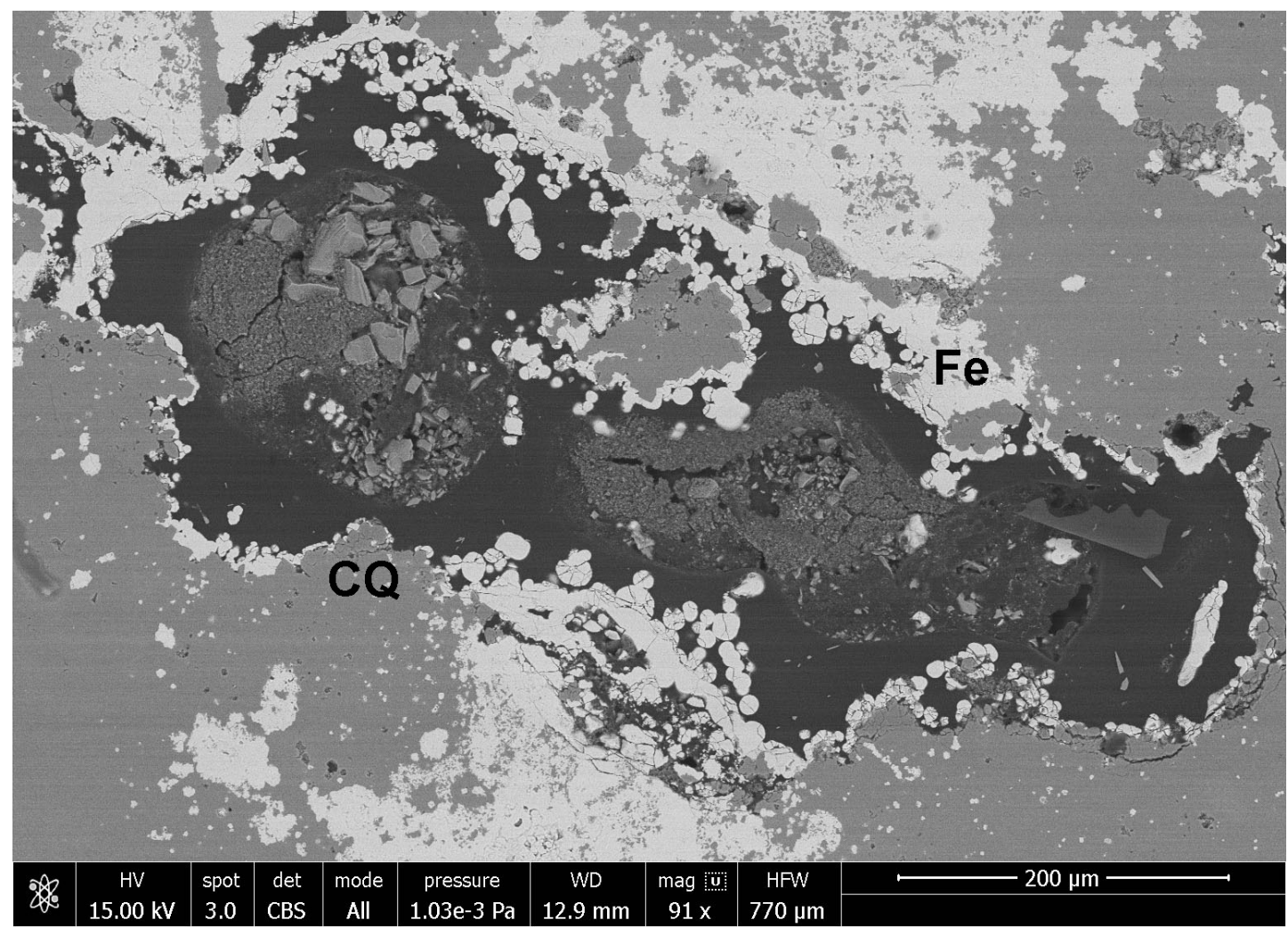

Figure 8. Back-scatter SEM image of iron oxides (Fe) cementing open pores, 
and apparently replacing cryptocrystalline quartz cement (CQ) in the Bradenham Coppice sample. Scale bar $=200 \mu \mathrm{m}$.

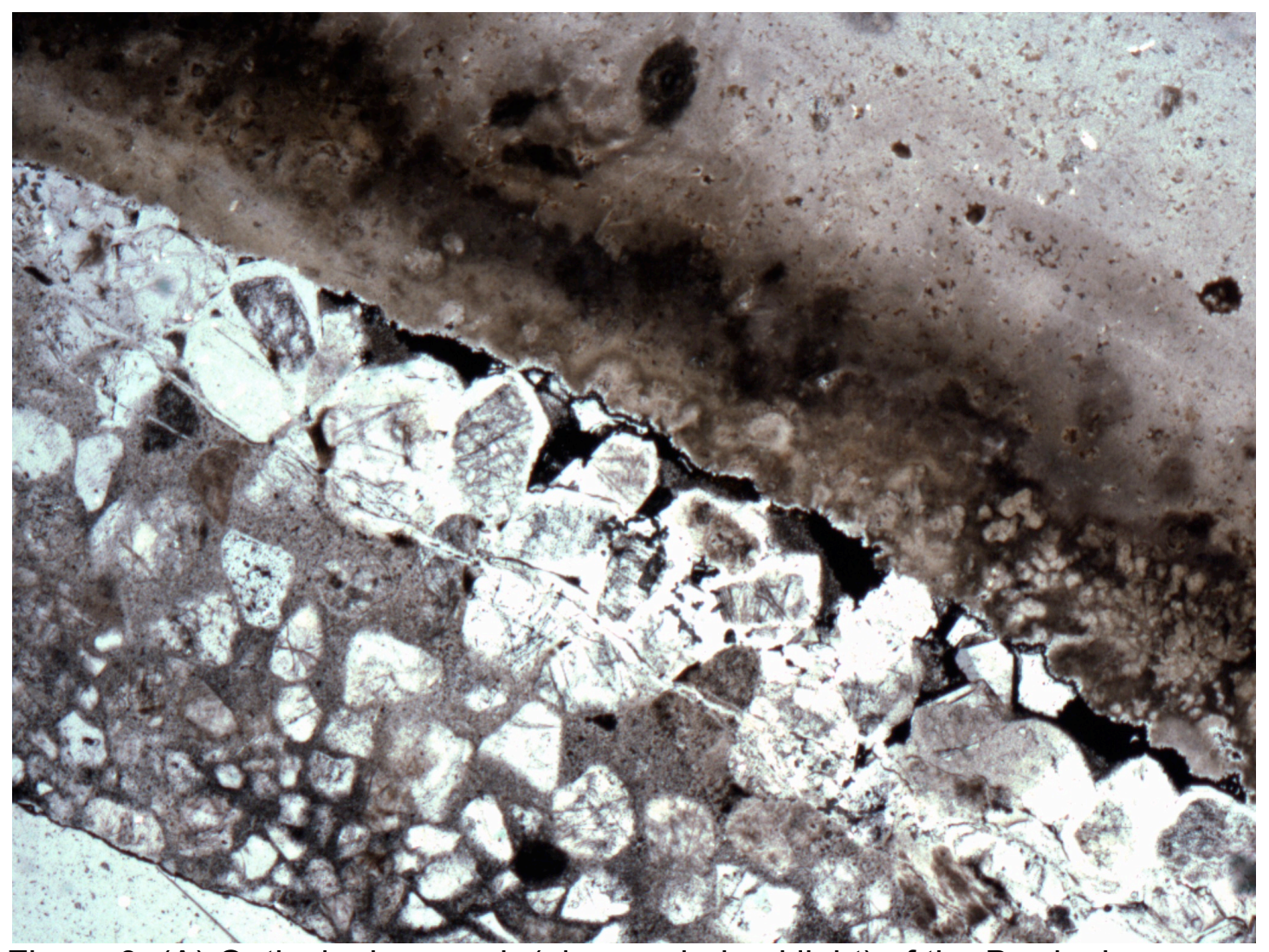

Figure 9. (A) Optical micrograph (plane polarised light) of the Bradenham Coppice sample showing quartz cement adjacent to a flint pebble. Nearest to the grain, macroquartz has developed as syntaxial overgrowths on sand grains, but has not completely cemented the available pore-space. Further from the flint, the cement is cryptocrystalline. Field of view $=5 \mathrm{~mm}$. 


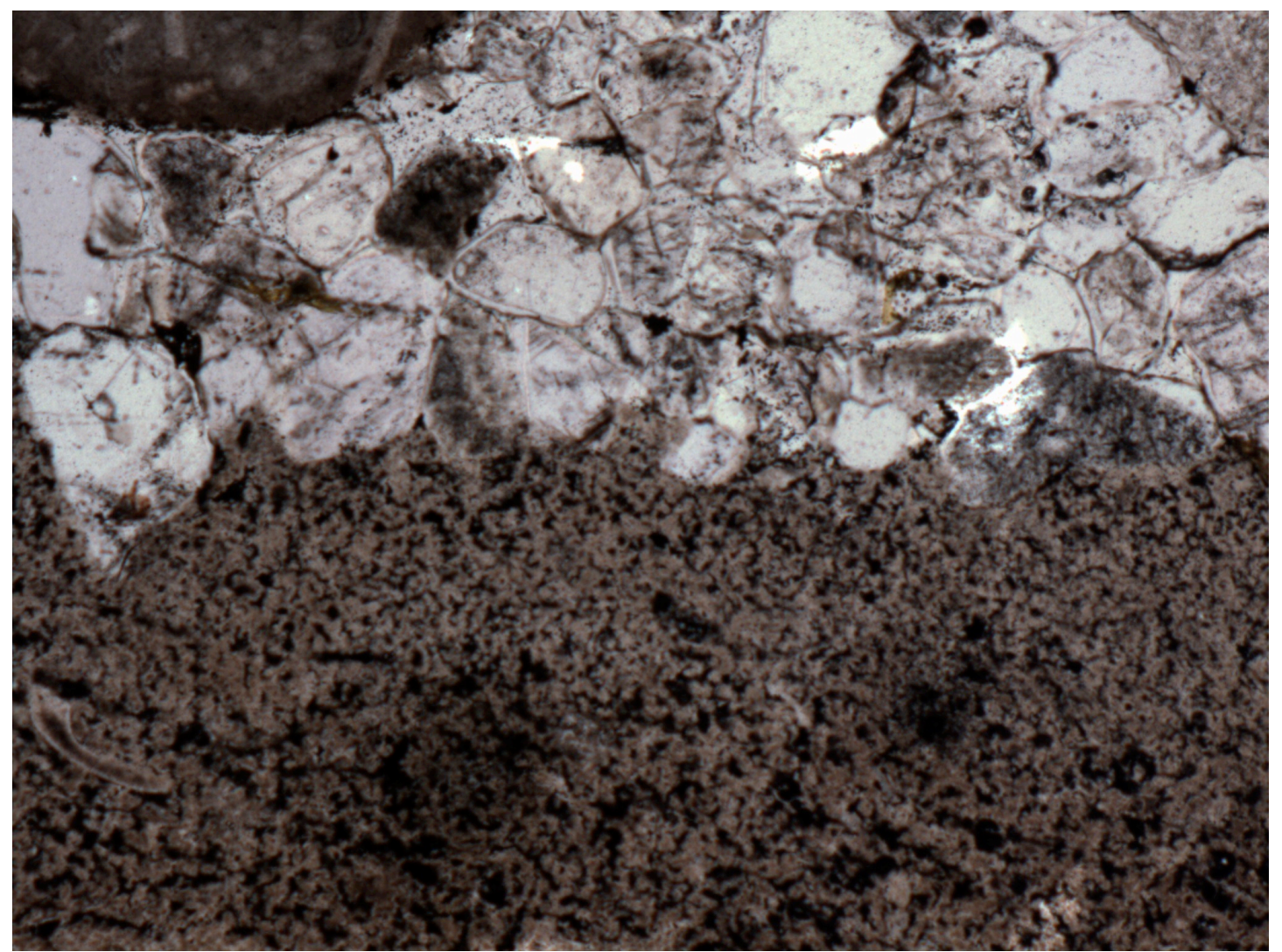

(B) Optical micrograph (plane polarised light) of the Puckeridge sample.

Syntaxial quartz overgrowths show an irregular boundary with a flint pebble, implying that the quartz cement has partially replaced the flint. Field of view $=$ $2.5 \mathrm{~mm}$.

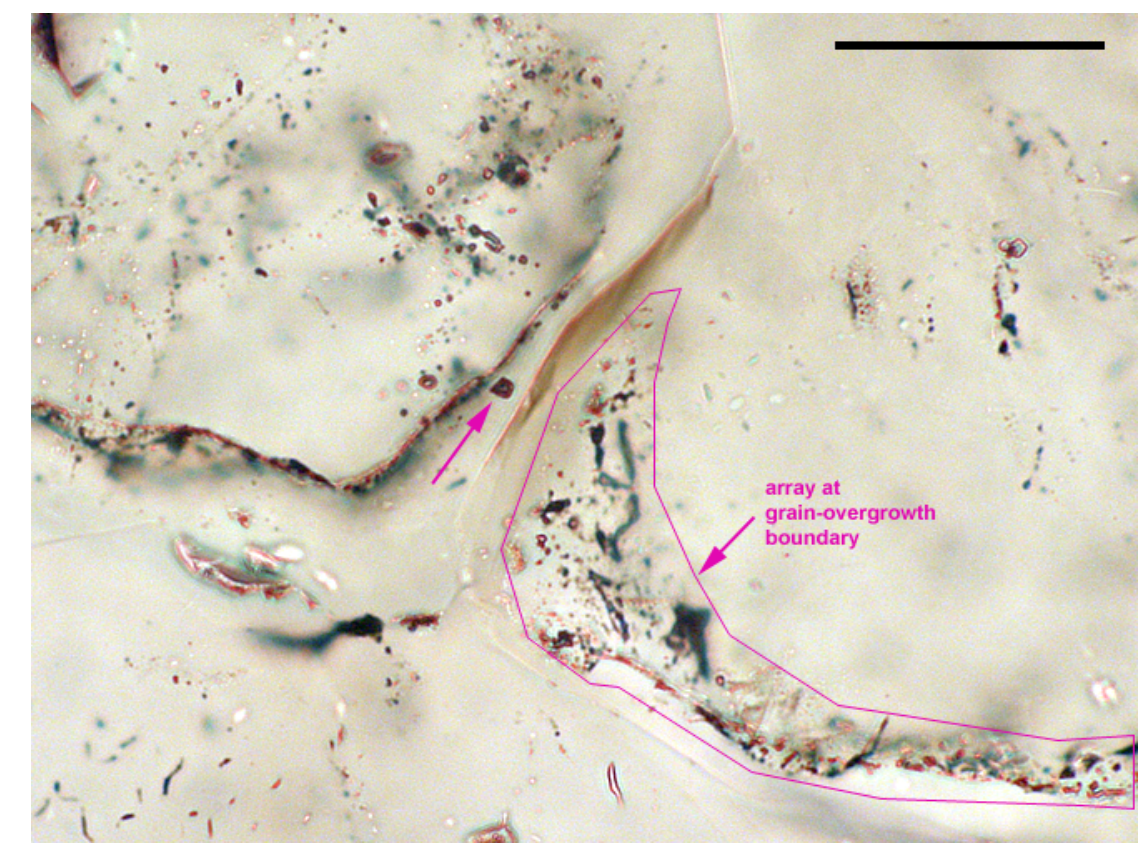

Figure 10. Optical micrograph of double polished thin section of the Bradenham Coppice HPS, showing possible diagenetic fluid inclusions and inclusion arrays in quartz overgrowths, as indicated by arrows and outline. Scale bar $=25 \mu \mathrm{m}$.

Tables 


\begin{tabular}{|c|c|c|c|c|c|}
\hline $\begin{array}{l}\text { Geographical } \\
\text { area }\end{array}$ & Locality & $\begin{array}{l}\text { Associated } \\
\text { sediments }\end{array}$ & Lithology & Clast types & $\begin{array}{l}\text { General silcrete } \\
\text { fabric }\end{array}$ \\
\hline $\begin{array}{l}\text { Bradenham } \\
\text { Puddingstone, } \\
\text { north-west } \\
\text { London Basin }\end{array}$ & & $\begin{array}{l}\text { On/in Chalk Head } \\
\text { over The Chalk, } \\
\text { down slope from } \\
\text { Clay-with-Flints }\end{array}$ & $\begin{array}{l}\text { Breccio-conglomerate } \\
\text { to pebbly moderately- } \\
\text { to poorly-sorted } \\
\text { sandstone }\end{array}$ & $\begin{array}{l}\text { Sub-rounded to sub- } \\
\text { angular flint pebbles } \\
\text { to cobbles, matrix } \\
\text { grains are moderately } \\
\text { sorted coarse silt to } \\
\text { CSE sand, sub- } \\
\text { angular to sub- } \\
\text { rounded }\end{array}$ & $\begin{array}{l}\text { GS-fabric, with quartz } \\
\text { overgrowth cements } \\
\text { (minor MQ and CQ) } \\
\text { and quartz cemented } \\
\text { micro-fractures }\end{array}$ \\
\hline $\begin{array}{l}\text { Chesham } \\
\text { Puddingstone, } \\
\text { north-west } \\
\text { London Basin }\end{array}$ & $\begin{array}{l}\text { Building site in the } \\
\text { town, exact locality } \\
\text { unknown }\end{array}$ & $\begin{array}{l}\text { Lambeth Group (no } \\
\text { greater detail } \\
\text { available) }\end{array}$ & $\begin{array}{l}\text { Clast-supported } \\
\text { conglomerate, with } \\
\text { sandy matrix }\end{array}$ & $\begin{array}{l}\text { Very well-rounded to } \\
\text { rounded flint pebbles, } \\
\text { matrix grains are well } \\
\text { sorted coarse silt to } \\
\text { VF sand, sub-angular } \\
\text { to sub-rounded }\end{array}$ & $\begin{array}{l}\text { GS-fabric quartz } \\
\text { overgrowth cement. }\end{array}$ \\
\hline $\begin{array}{l}\text { Hertfordshire } \\
\text { Puddingstone, } \\
\text { northern } \\
\text { London Basin }\end{array}$ & $\begin{array}{l}\text { White End Park } \\
\text { Farm, Ley Hill, } \\
\text { Chesham, } \\
\text { Buckinghamshire } \\
\text { Grid Ref. } \\
\text { TL990006 }\end{array}$ & $\begin{array}{l}\text { Pebbly clay and } \\
\text { sand over the Chalk; } \\
\text { fringing outlier of } \\
\text { Paleocene- Eocene } \\
\text { sediments }\end{array}$ & $\begin{array}{l}\text { Clast- to matrix- } \\
\text { supported breccio- } \\
\text { conglomerate to } \\
\text { pebbly sandstones } \\
\text { with sandy or fine- } \\
\text { grained matrix }\end{array}$ & $\begin{array}{l}\text { Very well-rounded to } \\
\text { rounded flint pebbles, } \\
\text { some smaller shard- } \\
\text { like flint, matrix grains } \\
\text { are moderately sorted } \\
F \text { to M sand, angular } \\
\text { to sub-rounded }\end{array}$ & $\begin{array}{l}\text { GS-fabric quartz } \\
\text { overgrowth cements; } \\
\text { GS- to F-fabric with } \\
\text { MQ to CQ cements; } \\
\text { M-fabric with CQ } \\
\text { cement }\end{array}$ \\
\hline \multirow[t]{2}{*}{$\begin{array}{l}\text { Hertfordshire } \\
\text { Puddingstone, } \\
\text { northern } \\
\text { London Basin }\end{array}$} & $\begin{array}{l}\text { Northaw Great } \\
\text { Wood } \\
\text { Grid Ref. TL282038 }\end{array}$ & $\begin{array}{l}\text { In situ in clayey } \\
\text { sand, probably } \\
\text { weathered Upnor } \\
\text { Formation }\end{array}$ & $\begin{array}{l}\text { Clast-supported } \\
\text { conglomerate, with } \\
\text { ferruginised sandy } \\
\text { matrix }\end{array}$ & $\begin{array}{l}\text { Very well-rounded to } \\
\text { rounded flint pebbles, } \\
\text { matrix grains are well } \\
\text { sorted VF to F sand, } \\
\text { sub-rounded to } \\
\text { rounded }\end{array}$ & $\begin{array}{l}\text { GS- to F-fabric quartz } \\
\text { overgrowth cement; } \\
\text { GS with MQ to } C Q \\
\text { cements (though } \\
\text { mostly obscured by } \\
\text { ferruginisation) }\end{array}$ \\
\hline & $\begin{array}{l}\text { Puckeridge Roman } \\
\text { Quarry (location not } \\
\text { available) }\end{array}$ & Not in place & $\begin{array}{l}\text { Clast-supported } \\
\text { conglomerate, with } \\
\text { sandy matrix }\end{array}$ & $\begin{array}{l}\text { Very well-rounded to } \\
\text { rounded flint pebbles, } \\
\text { matrix grains are well } \\
\text { sorted coarse silt to } \\
\text { VF sand, sub-angular } \\
\text { to sub-rounded }\end{array}$ & $\begin{array}{l}\text { GS-fabric quartz } \\
\text { overgrowth cement }\end{array}$ \\
\hline
\end{tabular}

Table 1. Characteristics of gravel-rich groundwater silcretes included in this study (CSE is coarse, $M$ is medium, $F$ is fine, and VF is very fine; GS-fabric is grain supported fabric, F-fabric is floating fabric (fragments of host material "floating" in cement that has replaced detrital clay, silt or sand), MQ indicates macroquartz cement and CQ, cryptocrystalline quartz cement. The Ley Hill and Bradenham Coppice data are adapted from Ullyott et al. (2015). 


\begin{tabular}{|c|c|c|}
\hline $\begin{array}{l}\text { Sample } \\
\text { Number }\end{array}$ & Description & $\begin{array}{c}\delta^{18} \mathrm{O} \\
\%, \text { VSMOW }\end{array}$ \\
\hline Pud 01a & Yellowish-stained quartz matrix (cement) & +17.6 \\
\hline Pud 01b & Yellowish-stained quartz matrix (cement) & +18.4 \\
\hline Pud 02 & 'Frosty' quartz/flint fragment & +28.6 \\
\hline Pud 03 & Unstained quartz matrix (cement) & +17.9 \\
\hline Pud 04 & $\begin{array}{l}\text { Quartz matrix (cement) containing sand-sized ( } \sim 0.1 \mathrm{~mm} \text { mean diameter) } \\
\text { grains }\end{array}$ & +17.6 \\
\hline Pud 05 & Grey quartz/flint pebble & +33.1 \\
\hline Pud 06 & Grey quartz/flint pebble & $+31.4 \pm 0.05$ \\
\hline Pud 07 & $\begin{array}{l}\text { Yellowish-stained quartz matrix (cement) containing sand-sized }(\sim 0.1 \mathrm{~mm} \\
\text { mean diameter) grains }\end{array}$ & +18.3 \\
\hline Pud 08 & $\begin{array}{l}\text { Yellowish-stained quartz matrix (cement) containing sand-sized }(\sim 0.1 \mathrm{~mm} \\
\text { mean diameter) grains and other lithic fragments }\end{array}$ & +19.6 \\
\hline Pud 09 & White quartz cement fragment & +21.8 \\
\hline Pud 10 & Grey-brown quartz/flint pebble fragment & +29.7 \\
\hline Pud 12 & Grey-brown quartz/flint clast fragment & +29.6 \\
\hline
\end{tabular}

Table 2. Oxygen isotope results for Bradenham Coppice puddingstone quartz separates. Bold typeface indicates the average of duplicate analysis. 